Atıf: Yılmaz, E. (2019). Mobil Ölçümlerle Ankara Şehri Isı Adası, Coğrafi Bilimler Dergisi/Turkish Journal of Geographical Sciences, 17(2), 281-317, doi: 10.33688/aucbd.600933.

\begin{tabular}{ccc} 
Coğrafi Bilimler Dergisi & Coğrafi \\
Bilimler & Dergisi \\
\hline & Turkish Journal of Geographical Sciences & e-ISSN:1308-9765 \\
\hline
\end{tabular}

\title{
Mobil Ölçümlerle Ankara Şehir Isı Adası
}

\author{
Urban Heat Island in Ankara with Travers
}

\section{Erkan Yılmaz*a}

\begin{tabular}{l} 
Makale Bilgisi \\
\hline DOI: \\
10.33688/aucbd.600933 \\
\hline Makale Geçmişi: \\
Geliş: 07.08.2019 \\
Kabul: 03.09.2019 \\
\hline Anahtar Kelimeler: \\
Şehir Isı Adası \\
Ankara \\
Mobil Ölçüm \\
Gök Görüş Oranı \\
Şehir Isı Adası Şiddeti
\end{tabular}

\begin{tabular}{l} 
Article Info \\
\hline DOI: \\
10.33688/aucbd.600933 \\
\hline Article History: \\
Received: 07.08.2019 \\
Accepted: 03.09.2019 \\
\hline Keywords: \\
Urban Heat Island \\
Ankara \\
Travers \\
Sky View Factor, \\
Urban Heat Island \\
Intensity
\end{tabular}

$\ddot{O} z$

Ankara'nın morfolojik olarak bir çanakta yer alması, şehir sakinleri için kalitesiz hava koşulları yaratmakta, bu olumsuz koşullar bazı dönemlerde şehir ısı adası (ŞIA) etkisiyle daha da artmaktadır. Bu çalışmada, Ankara şehrinde ŞIA'nın özelliklerinin belirlenmesi amaclyla 12 ay boyunca her ay için 1 gece 1 gündüz mobil ölçümler yapılmış, sonuçlar değerlendirilmiş ve istatistiksel yöntemler kullanılarak analiz edilmiştir. Bu değerlendirmelere göre, şehrin kuzey falezi Yükseltepe Kavşağı'nda, güney falezi ise Turan Güneş Caddesi'nde oluşmaktadır. Ulus ve Klzllay'da iki ayr zirve meydana gelmekte, falez ve zirveler arasında ise şehir platosu yer almaktadır. Şehir platosu içerisinde sıcaklık çukuru ve tepeleri görülmekte, bu durum şehir içi arazi kullanımı ve trafik yoğunluğu ve şehir yapısı özelliklerinden kaynaklanmaktadır. Şehirde oluşan ŞIA, yaz aylarında (kurak dönemde) daha belirginleşmekte, sicaklıklar şehir merkezinden uzaklaştıkça gündüzleri 0,2 geceleri $0,4^{\circ} \mathrm{C}$ azalmaktadır. Gök görüş oranı değerlerinin arttığı sahalarda sicaklıklar düşmektedir. Sicaklık dağıllşında yükselti de etkili olmakta, bu durum özellikle yüksek basınç koşullarında daha görünür hale gelmektedir.

\footnotetext{
*Sorumlu Yazar/Corresponding Author: Erkan Y1lmaz, eryilmaz@ankara.edu.tr

a Ankara Üniversitesi, Dil ve Tarih-Coğrafya Fakültesi, Coğrafya Bölümü, Ankara, Türkiye, http://orcid.org/0000-0002-38213648
} 


\section{Giriş}

Arazi örtüsü sürekli değiştirilmekte, bu değişim dolaylı olarak iklimi de etkilemektedir (Findell vd., 2009; Kalnay ve Cai, 2003). Geçmiş dönemlerde kırsal alandaki arazi değişimi olarak tanımlayabileceğimiz değişim süreci, nüfus büyüklüğüne bağlı olarak değişmiş, bazı dönemlerde bu değişim hızlanmıştır. Endüstri devrimiyle arazi örtüsü değişimi ivme kazanmış (Betts vd., 2007; Pielke vd., 2011), insanoğlunun atmosferin bileşimine olan etkisi de geçmiş dönemlerle kiyaslanamayacak şekilde artmıştır (Stocker vd., 2014). Çevresel değişim günümüzde en şiddetli halini almış ve bu etkinin azaltılması için küresel ölçekte sayısız çalışma başlatılmıştır. Ekonomik üretim alanları ve şehirsel yerleşim alanları, çevresel değişimin çok yoğun yaşandığı ve etkisinin de iyi bilindiği yerler halini almıştır. Küreselleşen dünya mobiliteyi artırsa da insanları belli merkezlerde toplanmaya yönlendirmiş, bir şehirde 40 milyona yakın (Tokyo-Japonya) (WCP, 2019) insanın birlikte yaşamasına neden olmuştur. Buralarda arazilerin planlı-plansız bir şekilde kullanımını, arazi kullanım-örtüsü değişimini beraberinde getirmiş, değişim sadece arazi kullanım değişimi ile sınırlı kalmamış iklimsel anlamda da küresel, bölgesel ve yerel olarak enerji bilançolarında farklılıklar oluşmuştur.

Sera gazı salınımı artışı ile birleşen arazi örtüsü değişimi, iklim değişiminin hızlanmasına ve belli yerlerdeki değişimin artmasına sebep olmuştur. Bu değişimle şehirler, çevrelerinden farklı bir hal almış, farklı sıcaklık, yă̆ış, nem, rüzgâr koşulları ile karakterize edilmeye başlanmış (Landsberg, 1981; Oke, 1982, 2002), şehir 1sı adaları (ŞIA) oluşmuştur. Çevrelerine göre daha sicak ve soğuk olabilen şehirsel alanlarda 1sıtma ve soğutma ihtiyaçlarında farklılıklar oluşturmakta, sıcaklık streslerine neden olmaktadır (Bounoua vd., 2009; Lee vd., 2009; Tomlinson vd., 2011; Zhang vd., 2011). Şehirlerde yaşayan yoğun nüfus ve endüstri faaliyetine bağlı olarak hava kirliliği artmaktadır (Lin vd., 2008). Hava kirliliğine neden olan kirleticiler gündüzleri albedoyu artırırken geceleri soğumayı azaltmakta (Zheng vd., 2018), şehirleri enerji deposu haline getirmektedir. Şehirler, bu kirleticiler nedeniyle hem dikey hem de yatay görüş oranının azaldığı bölgelerdir (Cheng ve Tsai, 2000; Gaillard vd., 2010). Şehirlerde hidrolojik döngü kesintiye uğramakta (Yang vd., 2010), bu da gizli 1sı kullanımını azaltmakta ve daha değişken sıcaklık şartlarının oluşmasını körüklemektedir. ŞIA'lar, şehirsel alanın genişlemesine, nüfusun artmasına (Oke, 1973; Peng vd., 2012) ve dikey yönde şehir gelişimine bağlı olarak bu olumsuz etkisini artırmakta hem yoğun arazi örtüsü değişimi hem de atmosfer bileşimindeki değişim, bu sahaları iklimsel açıdan özel yerler olarak incelememize neden olmuştur. Şehirlerdeki farklı arazi kullanımı alanlarında farklı meteorolojik şartlar hâkim olmakta (Chieppa, Bush ve Mitra, 2018) bu da şehir içinde farklı ortamların oluşmasını sağlamaktadır. Şehirsel alan içinde sıcaklık dağılışı homojen değildir. Şehrin farklı yerlerindeki şehir yapısı ve fonksiyonlarına göre sıcaklık şekillenmektedir. Parklar, havuzlar, yeni yapılaşan alanlar, alçak binaların yoğun olduğu sahalar, şehrin geneline göre düşük sıcaklık özellikleri gösterir. Şehir merkezindeki yoğun trafiğin olduğu ekonomik faaliyet alanları, yüksek katlı bina alanları, toprak örtüsünün tamamen yapay malzeme ile kaplandığı sahalarda yüksek sıcaklıklar ölçülmektedir. Şehir ile kırsal alan arasındaki sıcaklık farkı, ŞIA şiddeti (ŞIAŞ) olarak belirtilmektedir. ŞIA şiddeti genel olarak, açık, sakin ve bulutsuz meteorolojik durumlarda artmaktadır. Özellikle yüksek basıncın hâkim olduğu, havanın açık-bulutsuz olduğu ve rüzgâr hızının azaldığı dönemlerde artmaktadır. Bunlar da zaten ideal ŞIA şartları olarak tanımlanmaktadır (Memon, Leung ve 
Chunho, 2008). ŞIA'nın optimum koşulları sağlandığında ŞIAŞ, hafta içinde hafta sonuna göre daha yüksek olmaktadır (Eastin vd., 2018).

Şehirlerin klimatolojik ve meteorolojik özellikleri birçok yöntemle incelenebilmektedir. Bu yöntemler arasında meteoroloji istasyonu kurarak meteorolojik ve iklim parametrelerindeki eğilimi ölçmek ya da çevresindeki sahalarla karşılaştırmak, uydu görüntüsü kullanarak çeşitli meteorolojik değişkenlerin incelenmesi, termal kamera kullanarak farklı yüzeylerdeki yansıma değerlerinin belirlenmesi gibi yöntemler bulunmaktadır (Yılmaz, 2016). Mobil ölçümler de bu yöntemlerden bir tanesidir. Mobil ölçümler, haraketli bir araçla yapılmakta, bir araç üzerine monte edilen farklı meteorolojik parametreleri ölçüm sensörler ile belli güzergâhlar gezilmekte ve ölçülen değerler kaydedilmektedir. Güzergâh boyunca konum belirleme işlemi de yapılarak ölçülen değerlerin lokasyonu sağlanmaktadır. Mobil ölçümler, bir saha hakkında farklı dönemlerde fakat aynı/yaklaşık zaman diliminde ayrıntılı ölçümler sunmaktadır.

Dünyanın birçok yerinde mobil ölçümler farklı araçlarla yapılmış-yapılmakta ve şehir iklimi çalışmalarında faydalanılmaktadır. Bu ölçümlerden biri (Oke, 1973) tarafından, Lawrence Çanağı'nda (ABD), nüfusu 2000 ile 2 milyon arasında olan yerleşmelerdeki ŞIAŞ’ın belirlenmesi için yapılmış, nüfus ile ŞIAŞ arasında ilişki incelenmiştir. Çalışma sonucunda, açık gökyüzü koşullarında yapılan sıcaklık ölçümlerinin rüzgâr hızı ile ters ilişkili olduğu görülmüş, ŞıAŞ'ın nüfus miktarının dördüncü dereceden kökü ile ilişkili olduğu ortaya konulmuştur. Başka bir çalışmada Vancouver'da (Kanada) mobil araç kullanılarak binaların duvarlarındaki yüzey sıcaklıkları ve caddelerdeki hava sıcaklıkları ölçülmüsştür (Voogt ve Oke, 1998). Çalışmada elde edilen sonuçlara göre duvarlardaki yüzey sıcaklıkları zamana ve caddenin uzanışına göre değişmektedir. Kuzey-güney uzanışlı caddelerde sabah ve öğleden sonra olmak üzere iki, doğu-batı uzanışlı caddelerde bir, kuzeybatı, güneydoğu uzanışlı caddelerde ise bir yüksek ikisi düşük değerli sıcaklık maksimumu (peak) oluşmaktadır. Arizona Devlet Üniversitesi (ABD) yerleşkesi çevresinde, bisikletle yapılan ölçümler kullanılmış ve merkezdeki park alanının yatay ve dikey yönde soğutma etkisi oluşturduğu görülmüsstür (Chow vd., 2011). Reading şehrinde (İngiltere) bisiklet kullanılarak 15 farklı tarihte yapılan mobil ölçümlerle şehirdeki sıcaklık dağılışı belirlenmeye çalışılmıştır (Melhuish ve Pedder, 1998). Ölçümler esnasında aynı nokta için başlangıç ve son ölçüm arasında en yüksek sıcaklık farkı $4,0{ }^{\circ} \mathrm{C}$ olarak belirlenmiştir. ŞıAŞ, ortalama olarak $2,5{ }^{\circ} \mathrm{C}$ belirlenirken, yüksek basıncın olduğu bir ölçümde bu değer $9,0^{\circ} \mathrm{C}$ ölçülmüştür. Çalışmada mobil ölçümler için aynı anda karşılıklı iki farklı ölçüm yapılması önerilmiştir. Hong Kong'da (Çin) Aster uydusunun görüntü aldığı saatte, 148 km hat boyunca yapılan hava sıcaklığı ölçümleri ile uydudan elde edilen verilerden üretilen yüzey sıcaklıkları arasındaki ilişkinin araştırıldığı çalışmada mobil ölçümler yapılmış (Nichol vd., 2009), hava sıcaklığı ile yüzey sıcaklığı arasında \% 80 ilişki tespit edilmiş, şehir ve kırsal alanlarda yapılan ölçümlerde, şehir sıcaklık falezinin hem yüzey sıcaklıklarında hem de hava sıcaklıklarında belirlenebildiği anlaşılmıştır. Portland'da (ABD) hafta içinde ve hafta sonunda, yaz aylarında, farklı arazi kullanım alanlarında yapılan mobil ölçümlerle, arazi kullanımı ve zamana bağlı sıcaklık özellikleri incelenmiş (Hart ve Sailor, 2009), farklı özelliklerdeki yeşil alanların sıcaklığı etkileme durumunun değiştiği belirlenmiştir. Vancouver'da kırsal alan ile şehirsel alan arasındaki nispi nem farklarının araştırıldığı çalışmada (Carraro vd., 2004), yerinde ölçümlerle birlikte mobil ölçümler 
kullanılmış, ölçüm $25 \mathrm{~km}$ hat boyunca, geceleri 0.5 , gündüzleri 0,6-0,8 saate tamamlanmıştır. Yaz gecelerinde, açık gökyüzünün olduğu zamanlarda yapılan ölçümlerde, nispi nem açısından kır ve şehirsel alanın benzer özellikler gösterdiği tespit edilmiştir.

Ankara, 2018 y1lında 5.5 milyonu aşan nüfusu (TÜIK, 2019- 2012 yılında yaklaşık 5 milyon), idari başkent oluşu, ticaret, sağlık ve eğitim açısından sunduğu firsatlar nedeniyle önemli bir şehirdir. Şehirleşme dinamikleri İstanbul'a göre farklı olduğundan ŞIA etkisi de değişmektedir (Karaca, Tayanc ve Toros, 1995). Şehirde oluşan ısı adası daha evvel incelenmiş (Çiçek ve Doğan, 2005), ŞIAŞ'ın şubat ayında $9{ }^{\circ} \mathrm{C}$ '1 aşabildiği, ŞIA'nın düşük rüzgâr hızının hâkim olduğu hava koşullarında daha yoğun yaşandığı anlaşılmıştır. Aynı çalışmada şehrin batısı ile merkezi arasında kurulan istasyon verileri kullanılmış ve şehir falezinin (Kırsal ile şehir geçişi esnasında sıcaklığın aniden arttığı yer) Yenimahalle'de, zirvenin (Sıcaklığın en yüksek olduğu yer) ise Emek-Gar civarında olduğu belirlenmiştir. Başka bir çalışmada (Çiçek vd., 2013) şehrin gündüzleri negatif, geceleri ise pozitif yüzey 1S1 adası özelliği gösterdiği anlaşılmıştır. Türkoğlu vd. (2012) tarafindan yapılan çalışmada yoğun yapılaşma alanlarındaki fizyolojik eşdeğer sıcaklıkların diğer alanlara göre yüksek olduğu, bu farklılığın mayıs-eylül arası dönemde daha yüksek olduğu belirlenmiştir. Ankara'da şehirleşmeye bağlı iklim değişimi 1970'lerden buyana etkili olmakta, bunun şehrin çevresine yansıması ve çevrelerdeki yerleşmelerle birleşerek artması 1990'ların ortalarına denk gelmektedir (Çalışkan ve Türkoğlu, 2014). Şehirde şiddetli yağışı ıün sayısı artmakta (Çiçek, 2004), şehirsel alan genişledikçe ŞIA alanı da büyümektedir (Yüksel ve Yılmaz, 2008; Yüksel ve Kuntay, 2009). Türkiye'de, Ankara dışındaki metropoller genel olarak denize yakındır. Ankara ise ortalama 850 metre yükseltide, kabaca $40^{\circ}$ enleminde, İç Anadolu Bölgesi'nde yer alan yarı-karasal iklime sahip bir şehirdir. Topografik olarak 3 taraftan kapalı bir çanakta yer alan Ankara, ŞIA'nın olumsuz etkilerinden daha fazla etkilenebilecek durumdadır. 1970'li yıllardaki hava kirliliği bu olumsuz etkinin nasıl bir ortam oluşturabileceği açısından önemlidir (Akalan, 1984).

Yukarıda görüldügü gibi Ankara şehri daha çok meteoroloji istasyonu verileri ve uydu görüntüleri ile incelenmiş, şehir ısı adası morfolojik birimleri ve yıl içindeki gösterdiği değişimler yeterli istasyon bulunmaması nedeniyle ayrıntılı bir şekilde belirlenememiştir. Şehir, 750-1200 metreler arasında yükseltilerde kurulu bir şehirdir. Dolayısıyla, sıcaklıklar açısından bu yükselti değişimi de etkili olmaktadır. Şehir için yükseltinin de etkisine dair çalışma mevcut değildir. Sıcaklıklar şehirsel alanlarda merkezinden çevreye doğru düşmekte bu düşme oranı zamana göre değişmektedir. Gök görüş oranı da farklı ısınma durumlarının ve sıcaklıkların oluşmasına neden olmaktadır. Bu açılardan da Ankara için yeterli bilgi bulunmamaktadır. Bu nedenlerle çalışmada;

a) Ankara'da şehir 1sı adası şekil ögelerinin kuzey-güney konumları nerededir? Bu yerler yıl içinde değişmekte midir? Şehrin morfolojik ögeleri her zaman belirgin bir şekilde oluşmakta mıdır?

b) Ankara şehrinde yükseltinin sıcaklık üzerine etkisi var mıdır? Varsa bu etki nasıldır?

c) Ankara şehrinde gök görüş oranları ile sıcaklık arasındaki bir ilişki nasıldır?

d) Ankara'da şehir merkezinden uzaklaştıkça sıcaklıklar nasıl değişir? 
e) Ankara'da ŞIAŞ hangi aylarda yüksektir?

f) Ankara'da şehir arazi kullanımının sıcaklıklar üzerine etkisi nasıldır?

Sorularına cevap bulmak amacıyla mobil ölçümler yapılmış ve istatistiksel analizler gerçekleştirilmiş, elde edilen sonuçlar, önceki çalışmalarla karşılaştırılarak değerlendirmelerde bulunulmuştur.

\section{Veri ve Yöntem}

\subsection{Mobil Ölçüm Güzergâhı ve Özellikleri}

Çalışmada mobil ölçümler yapılmış, ölçüm hattı Ankara şehrini kuzeyden güneye kat eden, kırsal, şehirsel ve bu ikisi arasında geçiş özelliklerine sahip sahalardan oluşan bir güzergâh olarak seçilmiştir. Güzergâh; yüksek ve alçak, kuzeye ve güneye bakan, düz ve eğimli yüzeylerin bulunduğu, şehrin merkezinden ve dış sınırından geçen bir hat olma özelliğindedir. Bu hat, arazi örtüsü ve kullanımı, bina kat sayıları, binaların birbirine uzaklığı, caddelerdeki ağaç yoğunluğu, yükselti, bakı ve cadde uzanışı bakımından farklı1ık gösteren bir güzergâh olma özelliğindedir (Şekil 1, Çizelge 1).

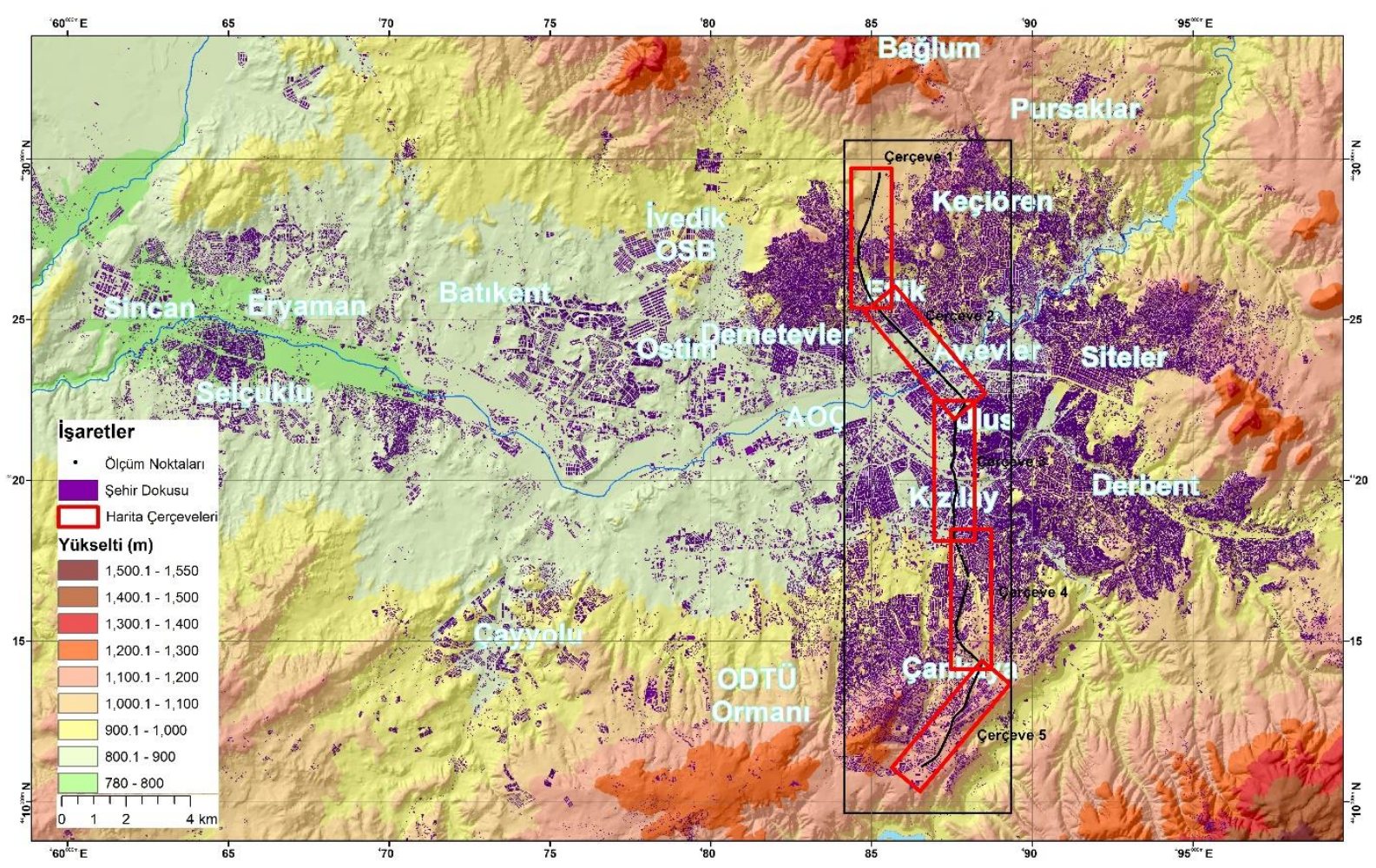

Şekil 1. Mobil ölçüm güzergah hattı ve haritalama için kullanılan çerçeveler

Ankara şehri, batıda Sincan civarında 750 metre yükseltiden başlar ve Ankara tren istasyonunda 850 metreye ulaşır. Dikmen civarında 1000 metreyi geçen yükseltilere çıkan yerleşme alanı, kuzeyde Keçiören civarında yine 1100 metrelerdedir. Şehrin büyük kısmı 800-900 metre yükselti aralığındaki Ankara Ovası ve çevresindeki sekilerde kurulmuştur (Şekil 1). Mobil ölçüm hattı, kuzeyde 1020 metrelerden başlamakta, Yükseltepe kavşağında 1060 metrelere çıktıktan sonra Ankara Çayı'na (840) kadar düşmektedir. Ankara Çayı'ndan sonra yükselti artmaya başlamakta, Kuğulu Parkı civarında 940 
metrelere ulaşmakta ve buradan sonra hızla artarak Cumhurbaşkanlığ 1 Caddesi'nde 1100 metrelere çıkmaktadır. Buradan sonra yavaş yavaş artan yükselti, ölçümün son alındığı noktada 1160 metre civarındadır (Şekil 2, Şekil 5).

Güzergâh boyunca arazi örtüsü belirlenirken karışık bir sınıflama yöntemi kullanılmıştır. Bunun nedeni, mevcut arazi örtüsü ve kullanım sınıflandırmalarının şehir iklimi çalışmalarında yetersiz kalmasıdır. Mesela, şehir içi yeşil alan denildiğinde, bir park akla gelmektedir. Fakat parkın ağaçlardan mı yoksa çimenden mi oluştuğu, parktaki sıcaklık bilançosunda etkilemektedir. Aynı şekilde, düzenli konut alanı denildiğinde sadece belli imar planına göre yapılmış saha anlaşılmaktadır. Oysa bu terim, konutların sıklığını, çevrelerindeki yeşil alan miktarlarını vermemektedir. Bu nedenle sınıflandırma yapılırken, bina sıklığı, yeşil alan durumu ve zemin özelliklerine dikkat edilmiştir (Şekil 2).
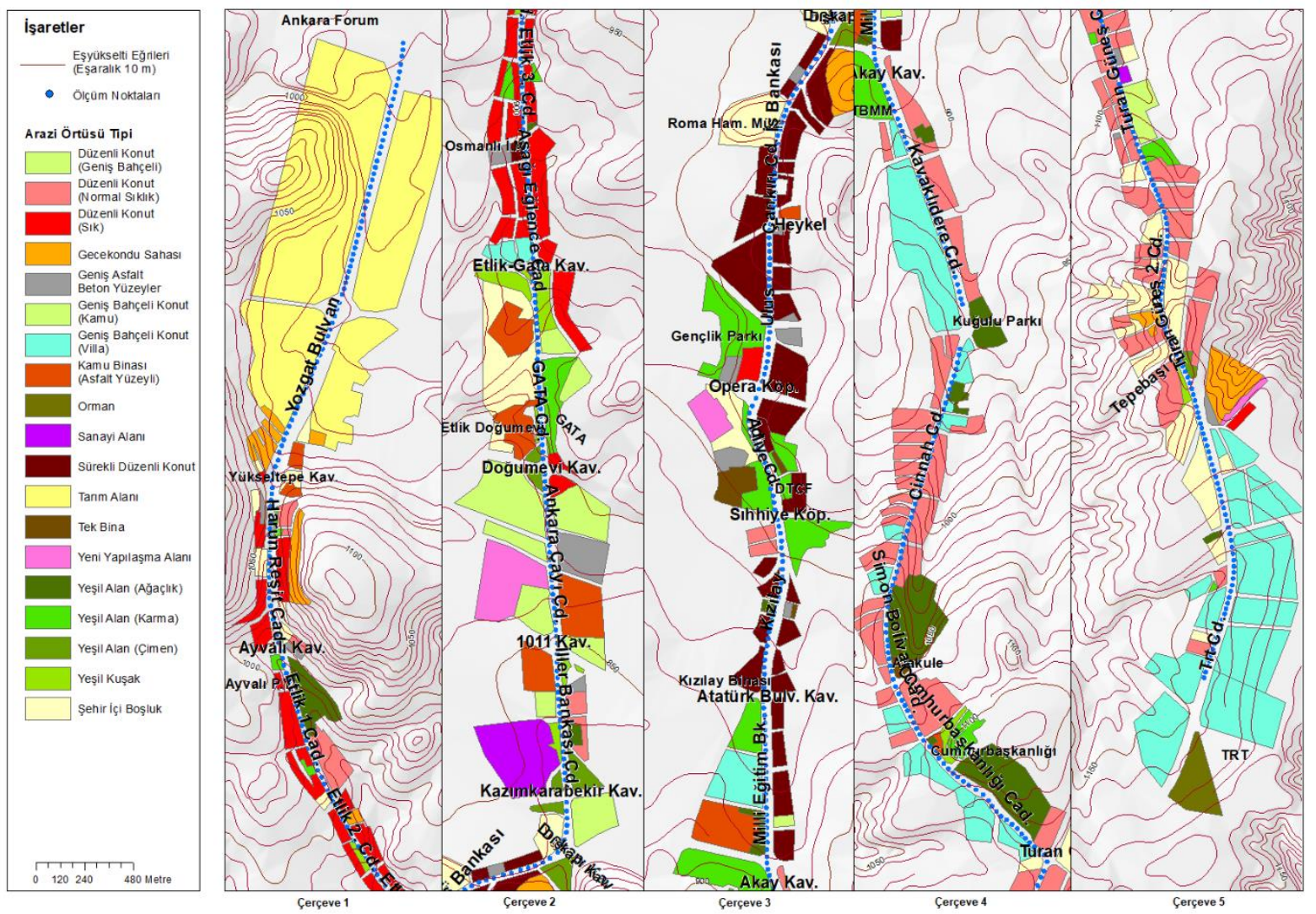

Şekil 2. Mobil ölçüm hattı çevresinde arazi kullanım durumu ve yükselti koşulları

Güzergâh hattının kuzeyinde, başlangıç alanında tarım alanları ve gecekondu sahaları bulunmakta yer almakta (2013 yılında), bu sahaların ardından düzenli konut alanları gelmekte, bunlar arasında farklı özellikte yeşil alanlar, kamusal alanlar bulunmaktadır. Şehrin merkezinde (Çankırı Caddesi, Ulus, Kızılay) sürekli düzenli konut alanları yer almakta, güneye doğru yine düzenli konut alanları, geniş bahçeli konut alanları, yeşil alanlar, şehir içi boşluklar ve orman alanları bulunmaktadır (Şekil 2, Şekil 5). Ölçüm hattının doğu ve batı kısmı bazı yerlerde asimetrik bir yapı göstermektedir. 
Ölçüm hattındaki binalar birbirinden farklı özellikler göstermektedir. Hat boyunca 1-25 katlı binalar yer almakta, bunların yapı malzemeleri değişmekte, renkleri de farklı olabilmektedir. Güzergâhın kuzeyinde genel olarak tek katlı gecekondular yer alırken, Harun Reşit Caddesi'nde 6-7, Etlik civarında 4, Ankara Çayı çevresinde ise 3 katlı binalar yer almaktadır. Çankırı Caddesi'nde kat sayısı 10'a çıkmaktadır. Ulus'ta 5-6 olan kat sayısı, Adliye çevresinde 6, Kızılay ve Milli Eğitim Bakanlığ 1 Caddesi'nde 10 civarındadır. Kat sayısı Cumhurbaşkanlığı Caddesi’nde 13, Turan Güneş Bulvarı'nda 5-6'dır. Güzergâhtaki en yüksek bina, 25 katlı olarak alınan Atakule'dir (Şekil 3, Çizelge $1)$.
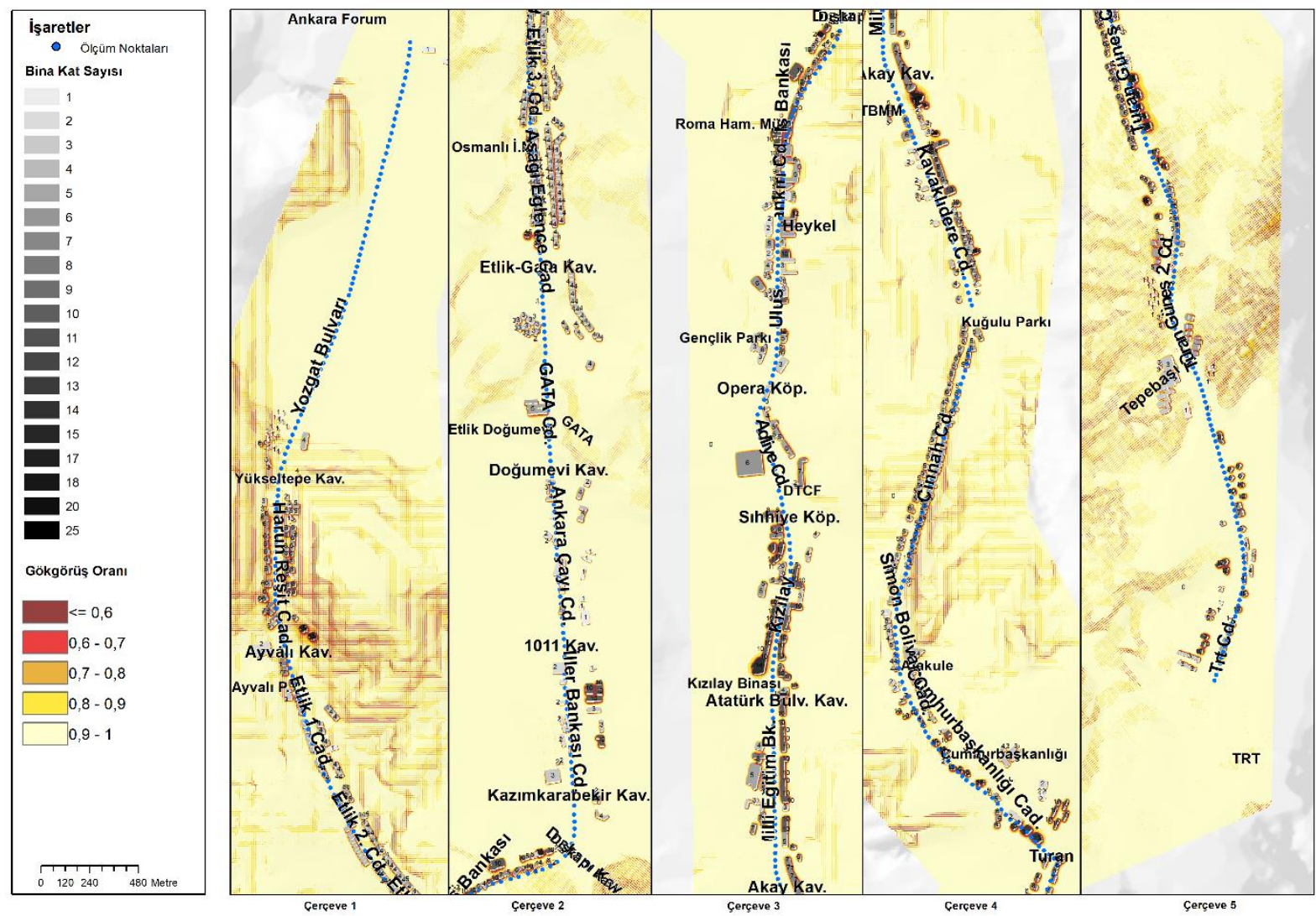

Şekil 3. Mobil ölçüm hattı çevresinde bina kat sayıları ve gök görüş ornaları

Çizelge 1. Mobil Ölçüm Güzergâhındaki caddelerin genel özellikleri

\begin{tabular}{llllrll}
\hline Cadde Adı & Arz. Kul- & GGO & Kat & Yükselti & Bakı & Uzanış \\
\hline Yozgat Bulvarı & Tarım Alanı & Çok Yüksek & 1 & $1000-1050$ & D, KD & K-G \\
\hline Harun Reşit Cad. & Sık Konut & Yüksek & $6-7$ & $1050-1000$ & D, B & K-G \\
\hline Etlik Cad. & Sık Konut & Düşük & 4 & $1000-900$ & D, KD & KB-GD \\
\hline Așağı Eğlence Cad & Sık Konut & Düşük & 4 & $900-880$ & G, GB & KB-GD \\
\hline GATA Cd. & Karma & Yüksek & 3 & $880-850$ & G, GD & KB-GD \\
\hline Ankara Çayı Cd. & Kamu Binaları & Yüksek & 2 & $850-835$ & Düz & KB-GD \\
\hline İler Bankası Cd. & Karma & Orta & $3-4$ & $840-860$ & Düz & KB-GD \\
\hline Çankırı Caddesi & Sürekli Konut & Çok Düşük & 10 & $860-870$ & B & KD-GB \\
\hline Ulus & Sürekli Konut & Çok Düşük & 5 & $860-870$ & B, GB & K-G \\
\hline Adliye Cad. & Karma & Orta & 6 & $855-850$ & B, Düz & K-G \\
\hline Kızlay & Sürekli Konut & Çok Düşük & 10 & $850-860$ & K, KB & K-G \\
\hline
\end{tabular}




\begin{tabular}{lllllll}
\hline Mil. Eği. Bak. Cad. & Sürekli Konut & Düşük & 10 & $860-880$ & K, KB & K-G \\
\hline Kavaklıdere Cd. & Karma & Orta & $7-8$ & $890-930$ & K, KD & K-G \\
\hline Cinnah Cd. & Nor. S1k. Kon. & Düşük & $4-6$ & $930-1060$ & K, KD & KD-GB \\
\hline Simon Bolivar Cd. & Nor. Sık. Kon. & Düşük & $6-7$ & $1060-1070$ & B, GB & KD-GB \\
\hline Cumhur. Cd. & Karma & Yüksek & 13 & $1070-1091$ & G, GB & KD-GB \\
\hline Turan Güneş Cd. & Nor. Sik. Kon. & Orta & $5-6$ & $1080-1180$ & K, KB, KD & KD-GB \\
\hline Trt Cd. & Gen. Bah. Kon. & Yüksek & $6-10$ & $1180-1055$ & K, KB & KD-GB \\
\hline
\end{tabular}

\subsection{Mobil Ölçüm Uygulamas1}

Mobil ölçümler binek bir araçla yapılmış, ölçüm aleti aracın bagaj kapağına monte edilmiştir (Şekil 4a). Burada amaç, ölçüm esnasında rüzgâr etkisinin minimuma indirilmesidir. Mobil ölçümlerde sıcaklığın ölçülmesi için Kestrel 4500 cep tipi taşınabilir hava ölçüm ve kayıt cihazı kullanılmıştır (Şekil 4a), Bu alet, bir usb port aleti kullanılarak bilgisayara bağlanabilmekte ve veriler aktarılabilmektedir. Kullanılan alet ayrıca, rüzgâr yönü, rüzgâr hızı, dik ve kuyruk rüzgâr ölçümü, kuru sıcaklık, rüzgâr soğurması, bağıl nem, ıslak hazne sıcaklığı, barometrik basınç, basınç eğilimi, basınca bağlı yükseklik gibi parametreleri ölçme kapasitesine sahiptir. Kullanılan ölçüm aleti 2 saniyeden 12 saate kadar aralıklarda istenilen sıklıkta ölçüm yapabilmekte, 4000 'den fazla veriyi kaydedebilmekte, ölçüm yaptığı zamanı gösterebilmektedir. Cep tipi (taşınabilir) hava durumu ölçüm cihazı, uygun sıcaklık, nem vb. ISO Kalibrasyon sertifikasına sahiptir ve teknik özellikleri ölçüm için uygundur (Çizelge 2). Ölçümler esnasında, konumun belirlenmesi amacıyla, el tipi GPS kullanılmıştır (Şekil 4b). Kullanılan GPS, zamana bağlı nokta oluşturabilmekte ve bilgiler bilgisayara kablo ile aktarılabilmektedir. GPS'in hata pay1 10 metreden azdır ve her yönden sinyal alabilmektedir (Şekil 4c).

Çizelge 2. Ölçüm aletine (Kestrel 4500) ait teknik özellikler

\begin{tabular}{lllll}
\hline Parametre & Ölçüm Aralığı & Doğruluk & Hassasiyet & Kalibrasyon Sonrası Sapma \\
\hline Rüzgâr Yönü & $0-360^{\circ}$ & $5^{\circ}$ & $1^{\circ}$ & $7 \mathrm{~m} / \mathrm{sn}$ 'nin altında 100 saatlik kullanımdan sonra $<\% 1$ \\
\hline Sıcaklık & $-45{ }^{\circ} \mathrm{C}-+125$ & $1{ }^{\circ} \mathrm{C}$ & $0.1{ }^{\circ} \mathrm{C}$ & - \\
\hline Nispi Basınç & $\%$ r $0-\% 100$ & $\% 3$ & $\% 0.1$ & 24 aydan sonra $\% 3$ \\
\hline Barometrik Basınç & $10-1100 \mathrm{mb}$. & $1.5 \mathrm{mb}$. & $0.1 \mathrm{mb}$. & 1 yıldan sonra $1 \mathrm{mb}$. \\
\hline
\end{tabular}



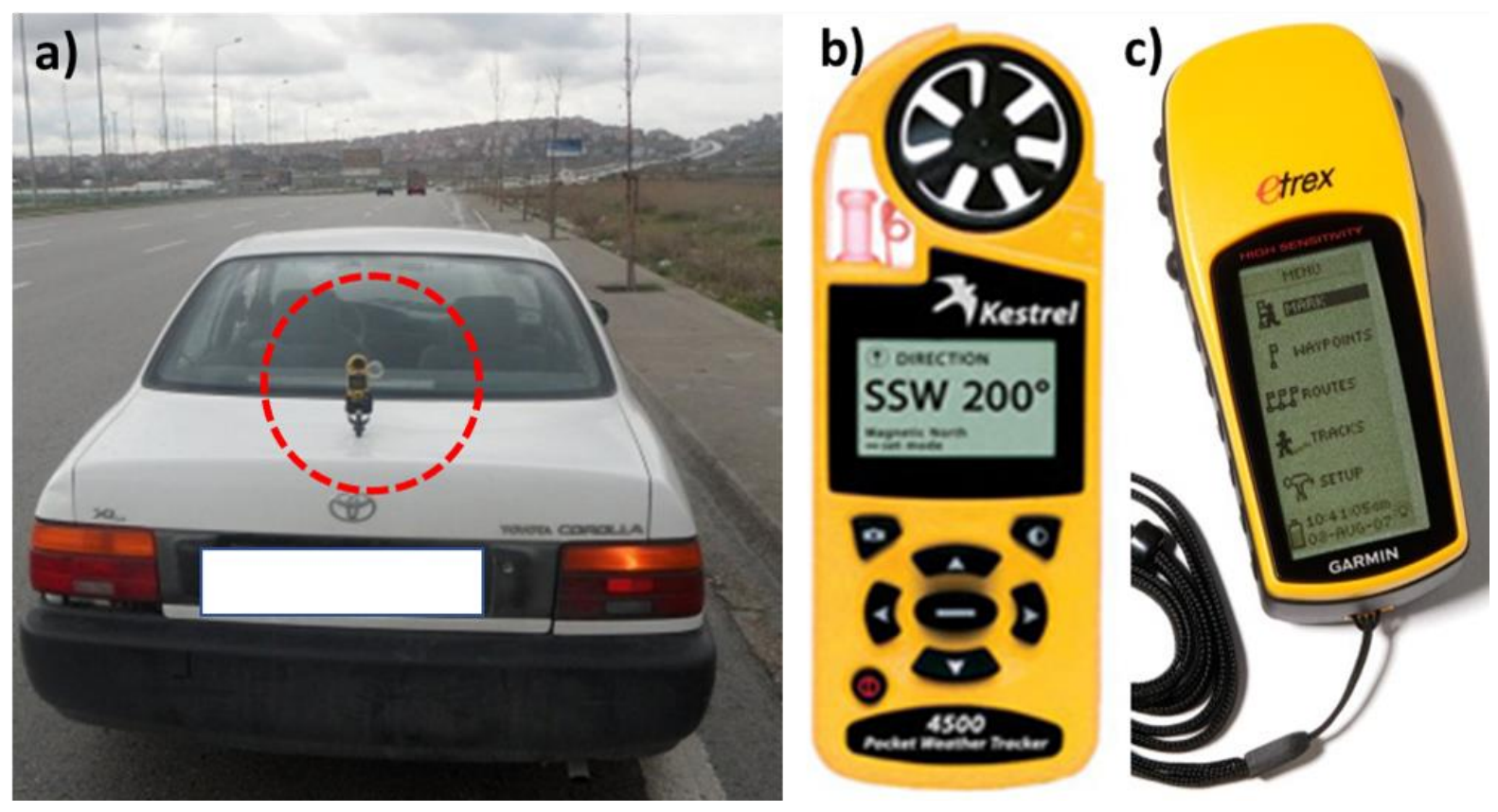

Şekil 4. a) Çalışmada kullanılan araç ve ölçüm aleti montajı b) Mobil ölçümlerde kullanılan ölçüm aleti, c) El tipi GPS

Mobil ölçüm esnasında, aracın hızına dikkat edilmiştir. Aracın hızı arttığında, göreli rüzgâr hızı artacak ve ölçüm aletinin ölçüm algılama süresi kısalacak buna bağlı olarak da hatalı ya da mekânsal kayma görülen ölçümler yapılacaktır. Bu çalışmada, araç ile ölçüm esnasında genellikle $25 \mathrm{~km}$ hız ile seyredilmeye çalışılmıştır. Fakat trafik yoğunluğu ve hava koşulları, bu hızda belli oynamalara neden olmuş, ölçümler 20-27 km arasındaki hızlarda gerçekleştirilmiştir. Bekleme anındaki ölçümler analiz dışı bırakılmıştır. Mobil ölçüm esnasında araç ile birlikte bir GPS aleti de taşınmış, ölçüm alınan noktaların konumu belirlenmiştir. Çalışmada veri ölçüm sıklığ 5 saniye olarak belirlenmiştir. Hem GPS hem de meteorolojik ölçüm aletlerinde 5 saniyelik periyot ayarlanmış ve ölçümler yapılmıştır. Ölçümlerde eşzamanlılığın sağlanması amacıyla her ölçümde, GPS ve meteorolojik ölçüm aleti saatleri eşleştirilmiş̧ir. Bu işlemin yapılması önemlidir. Çünkü GPS, saatini ilk bağlandığı uydudan almakta ve bu durum her ölçümde değişebilmektedir.

GPS'lerin köprü altlarında uydu bağlantıları kesilmekte ve nokta atma saniyeleri tekrar bağlantı sağlandığı zamanda başlamaktadır. Bu durumda da GPS'in attığı nokta saniyelerinde kaymalar yaşanmaktadır. Bu zorluğun ortadan kaldırılması amacıyla, meteorolojik ölçüm aletinde ve GPS kayıtlarında (log), 5 saniyelik yuvarlamalar yapılmıştır. Çalışmada 24 farklı ölçüm yapılmış (Çizelge 3), her ölçümde farklı ama birbirine yakın yerlerden ölçüm alınmıştır. Bu ölçümlerin karşılaştırılabilmesi amacıyla, belirli aralıklarla 595 (30 metrede bir) nokta seçilmiş ve tüm ölçüm noktaları bu noktalara çekilmiştir. Bazı ölçümlerde çok fazla ölçüm alınmış, bu ölçüm fazlalıkları değerlendirmeden çıkarılmıştır. Mobil ölçümler, trafik yoğunluğundan kurtulmak amaciyla cumartesi akşamları ile pazar sabahlarında yapılmıştır. Buna rağmen, kırmızı 1şıklarda durma zorunluluğu nedeniyle bazı yerlerde fazladan ölçüm alınmış, bu değerler sonradan analiz dışı bırakılmıştır. Ölçümler, 1 saatten fazla zamanda tamamlanmıştır. Bu nedenle ilk başlangıç ölçümü ile son alınan ölçüm arasında 
sıcaklık farkı oluşmuştur. $\mathrm{Bu}$ farkın giderilmesi amacıyla, tüm ölçümler başlangıç ölçümüne indirgenmiştir. Bu amaçla, Ankara meteoroloji istasyonu saatlik hava sıcaklığı verileri kullanılmış, ölçüm yapılan saatteki soğuma veya 1sınmaya bağlı olarak tüm ölçüm değerlerinde düzeltilmeye gidilmiştir.

Çizelge 3. Soğuk dönem gündüz ölçüm zamanlarına ve ölçüm günlerindeki güneş saatine ait bilgiler

\begin{tabular}{|c|c|c|c|c|c|}
\hline Ölçüm & Tarih & Ölçüm Saati & Toplam Süre & $\begin{array}{c}\text { Güneş } \\
\text { Doğuşu-Batılı }\end{array}$ & Geçen süre \\
\hline \multirow{12}{*}{$\begin{array}{l}\text { 汽 } \\
\text { : }\end{array}$} & 22.Oca.12 & 08:16:00-09:18:30 & 01:02:30 & $07: 05$ & $01: 11$ \\
\hline & 07.Şub.11 & 09:23:20-10:30:00 & 00:00:00 & $06: 51$ & $02: 32$ \\
\hline & 13.Mar.11 & 09:22:00-10:31:10 & 01:09:10 & $06: 04$ & $03: 18$ \\
\hline & 10.Nis.11 & 09:49:30-10:53:30 & 01:04:00 & $06: 19$ & 03:30 \\
\hline & 29.May.11 & 09:00:00-10:03:00 & 01:03:00 & $05: 23$ & $03: 37$ \\
\hline & 29.Haz.11 & 09:09:00-10:15:00 & 01:06:00 & $05: 22$ & $03: 47$ \\
\hline & 30.Tem.11 & 09:01:00-10:05:00 & 01:04:00 & $05: 44$ & 03:17 \\
\hline & 25.Ağu.11 & 08:36:00-09:41:35 & 01:05:35 & $06: 09$ & $02: 27$ \\
\hline & 25.Eyl.11 & 08:28:00-09:31:30 & 01:03:30 & $06: 38$ & $01: 50$ \\
\hline & 30.Eki.11 & 08:42:00-09:43:20 & 01:01:20 & $07: 15$ & $01: 27$ \\
\hline & 20.Kas.11 & 08:30:00-09:34:35 & 01:04:35 & $06: 39$ & 01:51 \\
\hline & 18.Ara.11 & 08:34:06-09:33:00 & $00: 58: 54$ & $07: 05$ & $01: 29$ \\
\hline \multirow{12}{*}{ ت્ّ } & 21.Oca.12 & $20: 24: 00-21: 27: 55$ & 01:03:55 & $16: 53$ & 03:31 \\
\hline & 06.Şub.11 & $20: 35: 05-21: 41: 25$ & 00:00:00 & $17: 13$ & $03: 22$ \\
\hline & 12.Mar.11 & $20: 46: 00-21: 51: 00$ & 01:05:00 & $17: 52$ & $02: 54$ \\
\hline & 09.Nis.11 & 21:17:00-22:23:40 & 01:06:40 & $19: 20$ & $01: 57$ \\
\hline & 28.May.11 & $20: 42: 30-21: 47: 30$ & 01:05:00 & $20: 08$ & $00: 34$ \\
\hline & 28.Haz.11 & 20:54:20-21:59:20 & 01:05:00 & $20: 21$ & $00: 33$ \\
\hline & 29.Tem.11 & 20:44:40-21:48:00 & 01:03:20 & $20: 06$ & $00: 39$ \\
\hline & 24.Ağu.11 & 20:48:00-21:53:00 & 01:05:00 & $19: 33$ & $01: 15$ \\
\hline & 24.Eyl.11 & 20:38:00-21:42:25 & 01:04:25 & $18: 43$ & $01: 55$ \\
\hline & 29.Eki.11 & 19:39:00-20:40:20 & 01:01:20 & $17: 50$ & 01:49 \\
\hline & 19.Kas.11 & $20: 35: 00-21: 36: 32$ & 01:01:32 & $16: 29$ & 04:06 \\
\hline & 17.Ara.11 & 20:33:00-21:38:00 & 01:05:00 & $16: 24$ & 04:09 \\
\hline
\end{tabular}

Not: Geçen süre, güneş doğuşundan ya da batışından ölçüm başlangıç anına kadar geçen süreyi ifade etmektedir.

\subsection{Gök Görüş Oranı Tespiti (GGO)}

Gök görüş oran1, herhangi bir yerin gökyüzünü görme yüzdesini ifade etmektedir. $\mathrm{Bu}$ oran birçok yöntemle belirlenebilmektedir. Bunların başında balık gözü merceğe sahip kamera ile bir noktadan gökyüzüne ait fotoğraf alımı ve bu fotoğraftaki gökyüzü oranın tespitine dayanmaktadır (Debbage, 2013). Bir diğer yöntem ise, yüksek çözünürlüklü arazi modelinin belirlenmesi ve bu modelden çeşitli algoritmalar kullanılarak noktalara ait GGO değerlerinin tespitidir (Böhner ve Antonić, 2009; Häntzschel, Goldberg ve Bernhofer, 2005; Kastendeuch, 2013). Bu çalışmada, çok fazla noktaya ait GGO değerinin tespiti gerektiğinden, yüksek çözünürlüklü arazi modeli oluşturulmuş ve sıcaklık ölçümü yapılan 595 nokta için GGO değerleri belirlenmiştir. Arazi modeli, 1:25000 ölçekli topografya haritasındaki yükselti bilgileri ile güzergâh hattındaki binaların kat sayılarına göre oluşturulan üç boyutlu modelin birleştirilmesiyle elde edilmiştir. Elde dilen model, SAGA-GIS yazılımı kullanılarak GGO değerleri oluşturulmuştur. Bu yazılım, Böhner ve Antonić (2009) ve Häntzschel vd. (2005) tarafından oluşturulan algoritmaları kullanmaktadır. Oluşturulan modele göre, Etlik, Çankırı Caddesi, 
Ulus, Kızılay, Cinnah Caddesi çevrelerinde düşük, diğer kısımlarda yüksek GGO değerleri bulunmaktadır (Şekil 5).

Ölçümler değerlendirilirken, Ankara'da yer alan meteoroloji istasyonlarının (Ankara Bölge, Etimesgut, Yenimahalle, TBMM) ölçüm günü ve ölçüm saati verileri kullanılmış, basınç ve nispi nem durumları değerlendirilmiştir.

\section{4.Şehir Merkezine Uzaklık (MU)}

Şehir 1S1 adası etkisi şehir merkezine doğru artmakta ve bu sahalarda en yüksek farklar görülmektedir. Tüm şehirlerde olduğu gibi, Ankara şehir merkezi de yoğun ticaret yapılan, yüksek bina yoğunluğuna sahip bir sahadır. Gündüzleri şehrin en kalabalık mekânı olan bu merkez hem trafik yoğunluğu nedeniyle hem de yoğun şehirsel yapı özellik göstermesi nedeniyle diğer sahalara göre daha sıcak özellikler göstermekte ve şehirde sıcaklıkların zirve yaptığı yer olarak karşımıza çıkmaktadır. Mobil ölçüm yapılan hat boyunca Ankara iki farklı şehir merkezi barındırmakta, trafik yoğunluğu artmaktadır. Bunlarda biri Kızılay diğeri ise Ulus'tur. Bu iki merkezliliğin sıcaklık ölçümlerine de yansıdığı belirlenmiş, bu nedenle şehir merkezi olarak iki merkezin orta noktası olarak Opera Köprüsü seçilmiş. Opera köprüsü merkez kabul edildiğinde, ölçüm hattının başlangıcı ve sonu şehir merkezine yaklaşık 8.5 km uzaklıktadır (Şekil 5).

\section{5. Çoklu Regresyon ve Kullanımı}

Çalışmada, ölçülen sıcaklıların şehir merkezine uzaklık durumu, yükselti ve GGO'dan etkilendiği düşünülmüş ve bu değişkenlerin sıcaklık üzerindeki etkisi araştırılmak istenmiştir. Bu etkinin belirlenebilmesi amacıyla çoklu regresyon kullanılmıştır. Çoklu regresyon yönteminde, bağımlı yani açıklanan değişken ile bağımsız yani açıklayıcı değişkenler arasında bir model kurulur (Alpar, 2003). $\mathrm{Bu}$ modelde $\mathrm{Y}$ açıklanan değişkeni, X'ler bağımsız değişkenleri, $\beta$ 'lar ise regresyon katsayılarını vermektedir (Eşitlik 1). Bu çalışmada eşitlik 2 ile model kurulmuştur.

$$
\begin{aligned}
& Y=\beta_{0}+\beta_{1} X_{1}+\beta_{2} X_{2}+\cdots \ldots \ldots .+\beta_{k} X_{k}+e \\
& S=\beta_{0}+\beta_{1} G G O+\beta_{1} Y \ddot{\mathrm{u}} k+\beta_{1} M U+e
\end{aligned}
$$

Eşitliklerde, S ölçülen sıcaklı̆̆ı, GGO gök görüş oranını, Yük yükseltiyi, MU ise şehir merkezine uzaklık değişkenlerini ifade etmektedir. Çoklu regresyon analizinde tahmin edilen $\hat{\beta}$ değerleri, eşitlik 3’teki matris işlemleriyle elde edilmektedir. Bu değerler, bağımsız değişkenin, açıklanan değişkene etkisini vermektedir. 
Ölçüm Hattının

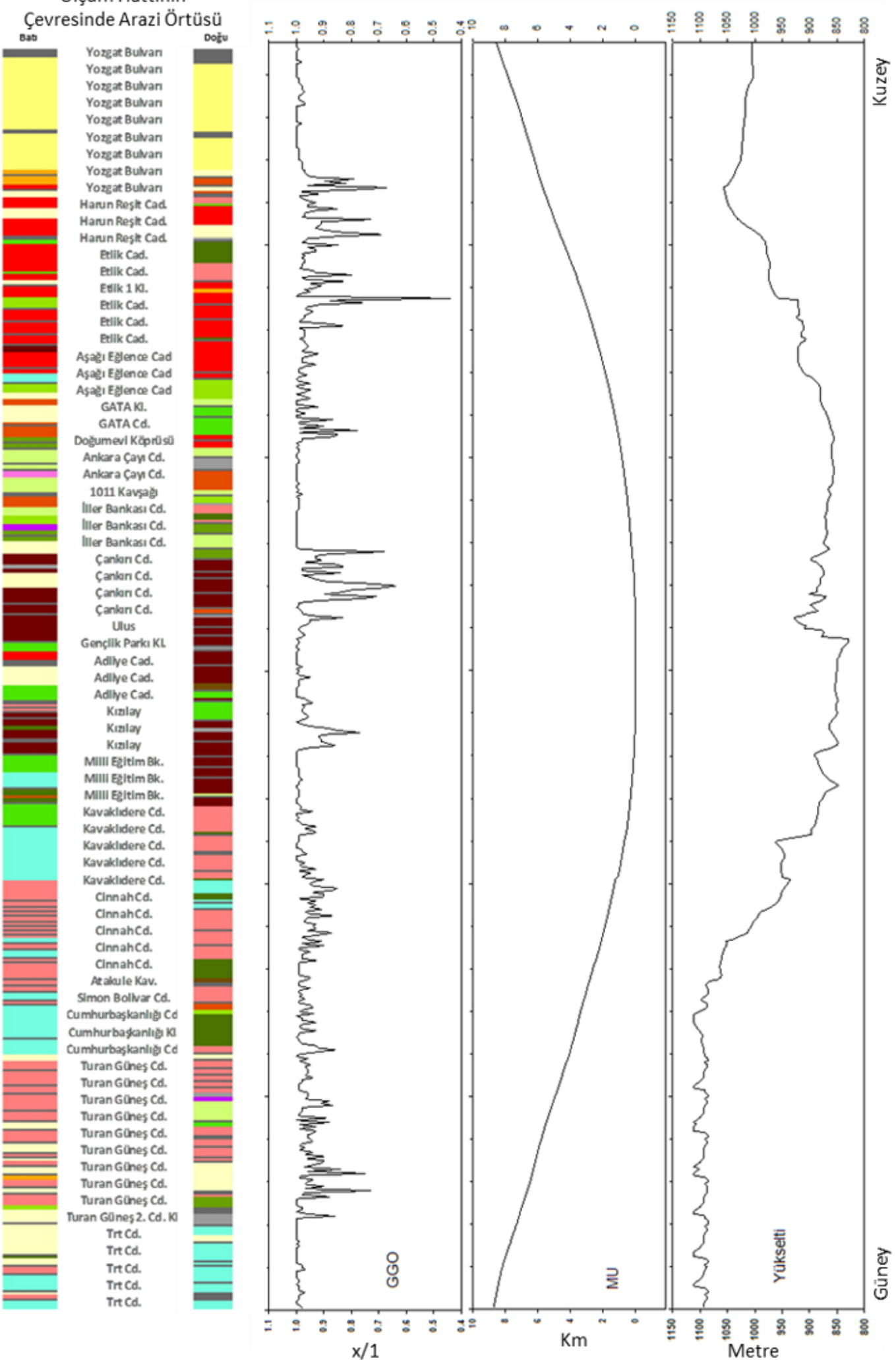

Şekil 5. Mobil ölçüm hattı özellikleri (Arazi kullanım renkleri Şekil 2 ile aynıdır). 


$$
\widehat{\boldsymbol{\beta}}=\left[X^{\prime} X\right]^{-1} X^{\prime} Y
$$

Regresyon analizinde varyans, eşitlik 4 kullanılarak belirlenmekte, daha sonra eşitlik 5 kullanılarak varyans -kovaryans matrisi elde edilmektedir. Regresyon katsayılarının varyans-kovaryans matrisinden belirlenen regresyon katsayısı hatalarına oranlaması ile regresyon katsayısına ait $\boldsymbol{t}$ değerleri elde edilmektedir. Bu değerler $\boldsymbol{t}$ dağılımına göre değerlendirilir ve $\mathrm{n}-2$ serbestlik dereceli $\mathrm{T}$ dağılımına göre değerlendirilerek olasılık (p) değerleri elde edilir ve hipotez sonucu belirlenir. Çalışmada $\alpha=0.05$ değeri alınarak hipotezler değerlendirilmiştir.

$$
\begin{aligned}
& s^{2}=\frac{1}{n} \sum(\hat{y}-\bar{y})^{2} \\
& \boldsymbol{V}(\widehat{\boldsymbol{\beta}})=\boldsymbol{s}^{2}\left[\boldsymbol{X}^{\prime} \boldsymbol{X}\right]^{-\mathbf{1}}
\end{aligned}
$$

Kurulan model için $\mathrm{R}^{2}$ yani belirleme katsayısı hesap edilmekte ve bu değer, kurulan modelin, sıcaklıklar için uygun olup olmadığı hakkında fikir vermektedir. $\mathrm{R}^{2}$ değeri eşitlik 6 ile belirlenmekte, bu değere ait hipotez testi $\mathrm{F}$ dağılımına göre yapılmaktadır. Eşitlik 7 ile elde edilen $\mathrm{F}$ değerine ilişkin olasılık değeri (p), $\alpha=0.05$ anlamlılık seviyesinde değerlendirilmiştir.

$$
\begin{aligned}
& \mathrm{R}^{2}=\frac{\sum(\hat{\boldsymbol{y}}-\overline{\boldsymbol{y}})^{2}}{\sum(\boldsymbol{y}-\overline{\boldsymbol{y}})^{2}} \\
& \mathrm{~F}=\frac{\mathrm{R}^{2} /(k-1)}{\left(1-\mathrm{R}^{2}\right) /(n-k)}
\end{aligned}
$$

\section{Bulgular ve Tartışma}

Çalışma bulguları, soğuk ve sıcak dönem şeklinde ikiye ayrılarak verilmiş, önce her döneme ait sıcaklıklar, şehrin iklim açısından morfolojik ögeleri ve arazi örtüsüne göre durumu anlatılmış, daha sonra tüm ayları kapsayacak şekilde modelleme sonuçlarına geçilmiştir.

\subsection{Soğuk Dönem Ölçümleri}

Soğuk dönem ölçümleri, ekim-mart aylarına ait ölçümleri kapsamaktadır. Soğuk dönemde Ankara, kar yağışının olduğu, don olaylarının görüldüğü, sabah saatlerinde terselmeye bağlı sislerin meydana geldiği bir yerdir (Çiçek, 2005). Soğuk dönem, bitki türüne göre değişmekle beraber, vejetasyon dönemi dışındaki bir zamandır. Bu nedenle bitkiler uyku dönemindedir. Yaprağını döken bitkiler bu dönemde çıplak haldedir ve sıcaklık açısından yapraklı döneme göre farklı tepkiler gösterirler. Kış aylarında Ankara'da nem oranları yüksektir. Ankara, soğuk dönemde gezici orta enlem siklonlarının geçişi esnasında cephelerden etkilenmekte ve yağış almaktadır (Sanır, 1948). Rüzgâr, basınç şartlarına göre değiş̧kenlik göstermekte ve her yönden esebilmekte ve kanalize olmakta (Barış, 1995), güneşlenme süresi de bu dönemde kısalmaktadır.

Gece ölçümlerinde, aralık ve mart aylarında parçalı bulutlu bir hava varken, kasım ve nisanda ayında az bulutlu açık, şubat ayında açık, ocak ayında ise parçalı bulutlu ve kar yağışlı bir gün yaşanmıştır. Ölçüm yapılan saatlerde, kasım, şubat ve mart aylarında açık gökyüzü koşulları hakimken, aralık ve nisan ayında az bulutlu hava koşullarında, ocak ayı ölçümü ise hafif kar yağışı esnasında yapılmıştır. Bu şartlara göre gece ölçümleri, şubat ve mart aylarında ideal, kasım ve aralık ayında yarı 
ideal, ocak ve nisan ayında ise ideal olmayan ŞIA koşullarında yapılmıştır. Gündüz yapılan mobil ölçümler, kasım, şubat ve mart ayında $\mathrm{YB}$, ocak ve nisan ayında $\mathrm{AB}$, aralık ayında ise AB-YB arası koşullar hâkimken yapılmıştır. Bu ölçümlerde yağış ve bulutluluk şartları aylara göre farklılık göstermiş, ölçüm saatlerinde ise kasım ve aralık ayında parçalı bulutlu, ocak ayında hafif kar yağışıı, şubat ayında açık, ekim ve mart aylarında ise az bulutlu gökyüzü koşulları gözlenmiştir. Bu şartlara göre ölçümlerin üçü ŞIA gelişimi için ideal, üçü ise ideal olmayan hava koşullarında yapılmıştır (Çizelge 4).

Soğuk dönemde hem gece hem de gündüz ölçümlerinde elde edilen ortalama sıcaklıklar, genel hava sıcaklığı gidişine uymamaktadır. Aralık ve mart aylarında ölçülen sıcaklıklar bu düzeni bozmaktadır (Çizelge 5). Aralık ayı sıcaklığı normale kasım ayına göre düşük çıkmalıdır. Aynı şekilde mart ayı sıcaklığı da şubat ayından daha yüksek çıkmalıdır. Ölçüm yapılan günler tek olduğu için o anki hava durumu mobil ölçümü etkilemiş ve genel hava sıcaklığı gidişine aykırı durumlar oluşmuştur. Zaten, soğuk bir ayda sıcak bir gün yaşanabileceği gibi, sıcak bir ayda soğuk bir günün yaşanması normal bir durumdur. Bu durum özellikle soğuk dönemde daha da sık yaşanmaktadır. Çalışmada mutlak sıcaklıklar yerine nispi sıcaklık durumu araştırıldığından, bu sıcaklık gidişindeki uyumsuzluklar dikkate alınmamıştır.

Çizelge 4. Soğuk dönem ölçümleri esnasında hava koşulları (AB-Alçak basınç, YB-Yüksek basınç

\begin{tabular}{|c|c|c|c|c|c|c|c|}
\hline & Ay & $\begin{array}{l}\text { Hakim } \\
\text { Basınç }\end{array}$ & Hava Koşulu (Gün) & $\begin{array}{l}\text { Hava Koşulu } \\
\text { (Ölçüm Saati) }\end{array}$ & $\begin{array}{l}\text { ŞIA } \\
\text { Durumu }\end{array}$ & $\begin{array}{l}\text { Basınç } \\
\text { Durumu (mb) }\end{array}$ & $\begin{array}{l}\text { Nispi Nem } \\
\text { Durumu (\%) }\end{array}$ \\
\hline \multirow{6}{*}{ گँّ } & Ekim & $\overline{A B}-Y B$ & Az bulutlu, açık & Açık & İdeal değil & 928-946 & $45-71$ \\
\hline & Kasım & $\mathrm{AB}-\mathrm{YB}$ & Az bulutlu, açık & Açık & Yarı ideal & 926-946 & $63-71$ \\
\hline & Aralık & $\mathrm{AB}-\mathrm{YB}$ & Parçalı bulutlu & Az bulutlu & Yarı ideal & 928-941 & $51-75$ \\
\hline & Ocak & $\mathrm{AB}$ & Parçalı bulutlu, kar yağışlı & Hafif karlı & İdeal değil & 924-933 & $75-85$ \\
\hline & Şubat & YB & Açık & Açık & İdeal & 934-946 & $63-75$ \\
\hline & Mart & YB & Parçalı bulutlu & Açık & İdeal & 939-953 & $62-75$ \\
\hline \multirow{6}{*}{ 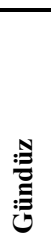 } & Ekim & $\overline{A B}-\mathrm{YB}$ & Az bulutlu, Açık & Az bulutlu & İdeal değil & $928-947$ & $68-87$ \\
\hline & Kasım & YB & Az bulutlu, Açık & Parçalı bulutlu & İdeal & 928-949 & $67-81$ \\
\hline & Aralık & $\mathrm{AB}-\mathrm{YB}$ & Parçalı bulutlu, hafif yağmurlu & Parçalı bulutlu & İdeal değil & 931-944 & $60-78$ \\
\hline & Ocak & $\mathrm{AB}$ & Parçalı bulutlu, kar yağışlı & Hafif karlı & İdeal değil & $922-937$ & $72-90$ \\
\hline & Şubat & YB & Az bulutlu, açık & Açık & İdeal & 934-944 & $65-84$ \\
\hline & Mart & YB & Az bulutlu & Az bulutlu & İdeal & $941-950$ & $53-65$ \\
\hline
\end{tabular}

Soğuk dönem gece ve gündüz ölçümlerinde en düşük mobil ölçüm sıcaklık ortalaması ocak ayında en yüksek ise aralık ayında çıkmıştır. Maksimum ve minimum sıcaklıklarda da aynı özellik gözlenmiştir. Ölçülen sıcaklıklara ait standart sapma değerleri en yüksek mart, en düşük ise ocak ayında belirlenmiştir. Sicaklık genliği ise en düşük ocak, en yüksek mart ayında ölçülmüştür (Çizelge 5). Ocak ayında hesaplanan düşük standart sapma değeri ile düşük sıcaklık genliği, ölçüm anındaki $\mathrm{AB}$ şartları ve kar yağışı ile ilişkilidir (Çizelge 4).

Çizelge 5. Soğuk dönem ölçümlerine ait tanımlayıcı istatistikler

\begin{tabular}{|c|c|c|c|c|c|c|c|}
\hline & Değişken & Ekim & Kasım & Aralık & Ocak & Şubat & Mart \\
\hline \multirow{6}{*}{ تِّ } & O. S. & 7.11 & 3.57 & 7.88 & -0.52 & 1.79 & 0.00 \\
\hline & Mak. S. & 9.49 & 6.21 & 11.58 & 0.67 & 5.17 & 3.54 \\
\hline & Min. S. & 5.02 & 0.82 & 5.63 & -1.94 & -1.17 & -4.28 \\
\hline & Std. S. & 1.09 & 1.23 & 1.37 & 0.61 & 1.68 & 1.44 \\
\hline & Genlik & 4.47 & 5.39 & 5.95 & 2.61 & 6.34 & 7.82 \\
\hline & O. S. & 3.97 & 2.66 & 9.03 & -0.59 & 1.35 & 3.11 \\
\hline
\end{tabular}




\begin{tabular}{rlrrrrrr}
\hline \multirow{2}{*}{} & Mak. S. & 5.70 & 5.01 & 12.03 & 0.22 & -2.24 \\
\cline { 2 - 7 } & Min. S. & 1.55 & 0.60 & 6.80 & -2.16 & -0.54 \\
\cline { 2 - 7 } & Std. S. & 0.93 & 1.10 & 1.24 & 0.49 & -0.68 \\
\cline { 2 - 7 } & Genlik & 4.41 & 4.41 & 5.23 & 2.38 & 1.03 \\
\hline
\end{tabular}

Not: OS- Ortalama sıcaklık, Mak. S.-Maksimum sıcaklık, Min. S.-Minimum sıcaklığı ifade eder.

Gece ölçülen sıcaklık genlikleri ile hesaplanan standart sapma değerleri tüm aylarda gece ölçümlerinde daha yüksek çıkmıştır. Bu durum, ŞIA'nın gece ölçümlerinde kendini gösterdiği, 1sınmadan daha çok soğumada kaynaklandığını ortaya koymaktadır (Çizelge 5).

Soğuk dönem gece ölümlerinde ŞIA'nın kuzey falezi hem gece hem de gündüzleri Harun Reşit Caddesi güneyinde oluşmuş olmasına rağmen, ocak ve şubat aylarında falez tam belirgin değildir (Şekil 6). Mart ayında ise Yozgat Bulvarı ortasında oluşmuştur. Gece ölçümlerinde falezin sıcaklık farkı $2^{\circ} \mathrm{C}^{\prime} \mathrm{a}$ yaklaşırken gündüz ölçümlerinde bu değer $1{ }^{\circ} \mathrm{C}^{\prime} 1$ n altındadır. Falezden sonra, Etlik Caddesi-İller Bankası Caddesi arası hem gece hem de gündüz ölçümlerinde ŞIA'nın platosu (Sıcaklığın zirveden düşük, kırsal alandan yüksek ve sıcaklık değişkenliğinin düşük olduğu yerler) özelliğindedir. Bu plato içerisinde sıcaklıklar değişmektedir. Bu değişkenliğe, ölçüm hattını doğu ve batıdan kesen yollar neden olmakta, burada oluşan şehir kanyonu kesintiye uğramakta, sıcaklık düşmektedir. Plato üzerinde özellikle geceleri GATA ve Ankara Çayı Caddesi'nde sıcaklık çukuru meydana gelmektedir. Bu cadde çevresinde yeşil alanlar bulunmakta bu da çukurun oluşmasında etkili olmaktadır. Ayrıca Ankara Çayı Caddesi (Ankara Çayı ve çevresi, bu çalışmada Ankara Çayı Caddesi olarak isimlendirilmiştir), ölçüm hattının en alçak yerini oluşturmakta, sıcaklığın yüksek olması beklenmektedir. Burada yer alan akarsu kanalı ve çevresinde rüzgâr kanalize olabilmekte bu da sıcaklığın düşmesine neden olabilmekte, bu durum daha çok gece ölçümlerine yansımaktadır. Kuzey platosu üzerinde yer alan 1011 Kavşağı, sıcaklık tepesi özelliği göstermektedir. Bu kavşak, Somsun yolu ile Etlik caddesinin birbirini kestiği, trafiğgin çok yoğun olduğu bir noktadır. Buradaki yoğun trafik ve kirletici miktarındaki fazlalık sıcaklığı artırmakta, sıcaklık tepesi rüzgâr koşullarına göre güneye kayabilmekte, tepe İller Bankası Caddesi’ne denk gelmektedir.

Kuzey platosundan şehir merkezine doğru Çankırı Caddesine geçilmekte, bu geçiş esnasında sıcaklıklar $1{ }^{\circ} \mathrm{C}$ civarında artmaktadır. Çankırı Caddesi, sürekli şehir yapısının olduğu, GGO değerlerinin düştüğü, şehir merkezine geçişte önemli bir cadde olması nedeniyle yoğun trafiğin olduğu bir şehir kanyonudur. Burada gece ölçümlerinde sıcaklık artışı yavaş olmasına rağmen, gündüz ölçümlerindeki sıcaklık artışı çok barizdir. Tam bir şehir kanyonu özelliği gösteren bu sahadan sonra Ankara için iki merkezden bir olan Ulus gelmekte ve birinci sıcaklık zirvesine ulaşılmaktadır. Buradaki sıcaklık zirvesi, gece ölçümlerinde çok belirgin değildir. Ulus Caddesi’nde GGO değerleri yüksek, bina kat sayısı da Çankırı Caddesi'ne göre düşüktür. Kızılay, Ankara için ŞIA'nın ikinci zirvesini oluşturmakta, sıcaklıklar yükselmektedir. Burada oluşan zirve, geceleri Ulus'a göre daha belirgin gündüzleri ise daha düşük sıcaklık farkı ile görülmektedir. Kızılay'da GGO değerleri Ulus'a göre daha düşüktür. Bu nedenle geceleri daha yavaş soğumakta gündüzleri daha geç isınmaktadır. Kızılay-Ulus arası, Adliye Caddesi'nin bulunduğu, çevresi yeşil alanlar ve kamu binalarıyla kaplı bir sahadır. Bu saha iki zirve arasında bir plato-sıcaklık çukuru özelliği göstermekte, sıcaklıklar düşmektedir. 


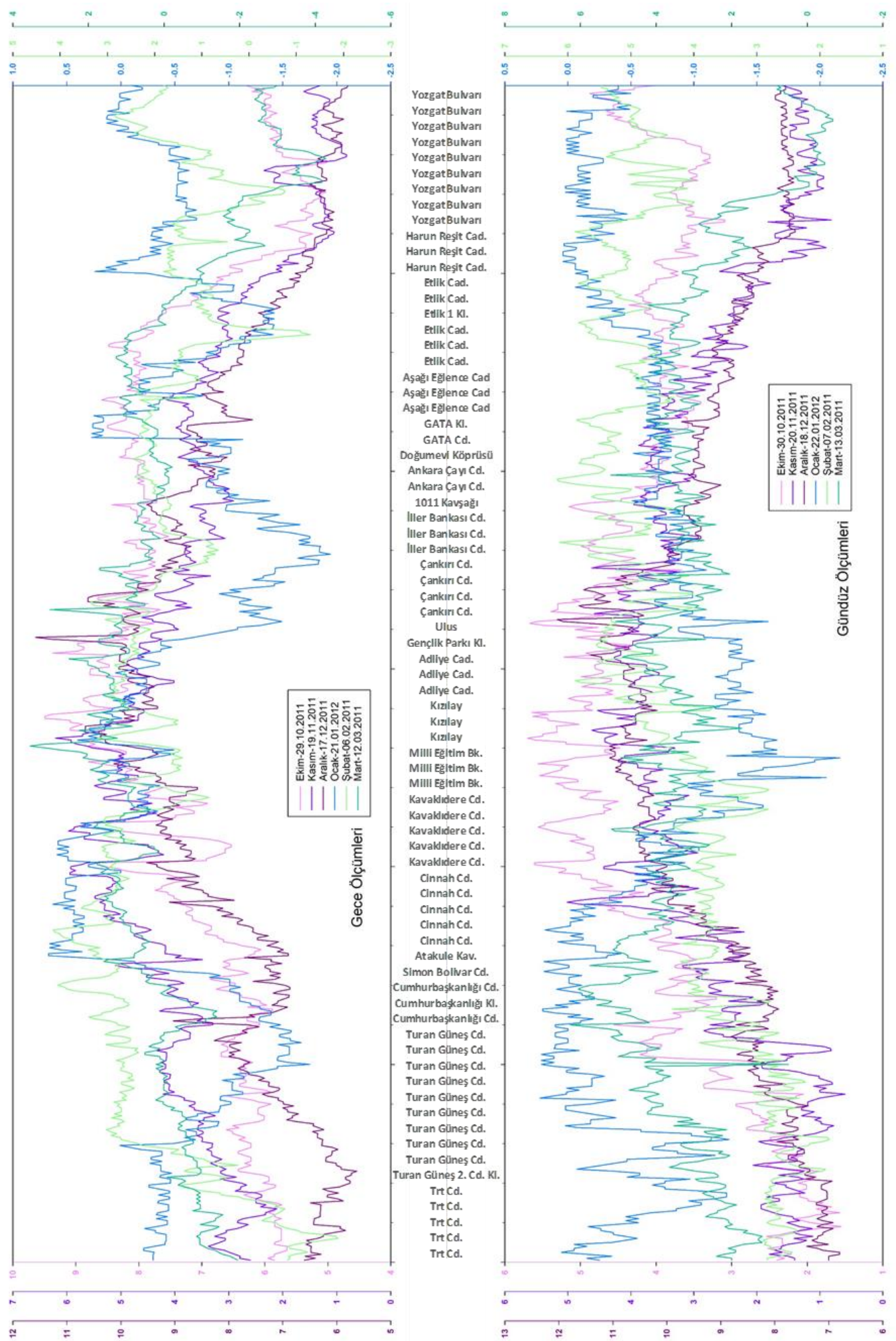

Şekil 6. Soğuk dönem ölçüm sonuçları (Düşey ölçeklerde sıcaklıklar ${ }^{\circ} \mathrm{C}$ tır ve her ay için ayrı renkte hazrlanmıştır). 
Kızılay'dan Kavaklıdere'ye geçişte TBMM ve çevresindeki yeşil alan bulunmaktadır. Burada sıcaklıklar düşmeye başlamakta ve Kavaklıdere'ye geçişte tekrar yükselmektedir. TBMM çevresi bir sıcaklık çukuru meydana getirmekte, bu çukur Kavaklıdere Caddesi'nde son bulmaktadır. Kavaklıdere ile Cinnah Caddesi arasında Kuğulu Park ve çevresinde elçilik binalarına ait yeşil alanlar yer almakta sıcaklıklar tekrar düşerek bir sıcaklık çukuru oluşturmaktadır. Cinnah Caddesi'ne sıcaklıklar hem gece hem de gündüzleri yükselmektedir. Bu durum caddede GGO değerlerinin düşük olmasından kaynaklanmakta, caddede ilerledikçe sıcaklıklar yükseltiye bağlı olarak düşmektedir. Atakule Kavşağı'na kadar düşen sıcaklıklar, buradaki trafik yoğunluğu nedeniyle yükselmekte, Simon Bolivar Caddesi'nde tekrar düşmeye başlamaktadır. Cumhurbaşkanlığı Caddesi boyunca düşük olan sıcaklıklar burada bir sıcaklık çukuru meydana getirmektedir. Cumhurbaşkanlığı Caddesi, asimetrik bir yapıdadır. Caddenin bir tarafı binalardan diğer tarafı yeşil alanlardan meydana gelmektedir. Daha sonra Turan Güneş Caddesi (Bulvarı) bulunmakta, bu bulvarda sıcaklıklar tekrar yükselmekte ve cadde sonuna doğru yükseltiye bağlı olarak düşmektedir.

ŞIA’nın güney falezi gece ölçümlerinde çok belirgin değildir. Kasım ve aralık aylarında TRT ile Turan Güneş Caddesi arasında oluşurken diğer aylarda belirgin bir falez oluşmamıştır. Gündüz ölçümlerinde ise şubat ve mart ayları haricinde Turan Güneş Caddesi ortasında oluşmuştur. Güney falezi kuzey falezine göre daha az eğimlidir. Sıcaklık daha yavaş düşmektedir. Falezden sonra TRT Caddesi’nde sıcaklıklar hem gündüz hem de gece ölçümlerinde yükselmekte, kırsal alana doğru sıcaklık artmaya başlamaktadır.

\subsection{Sicak Dönem Ölçümleri}

Sıcak dönem ölçümleri, nisan-eylül aylarında yapılan mobil ölçümleri kapsamaktadır. Bu dönemde Ankara'da hava sıcaklığı yüksektir. Bitkilerin vejetasyon döneminde olduğu, yaprağını döken bitkilerin yapraklandığı ve biyokütlelerini artırmaya başladığı bir dönemdir. Sıcak dönemde Ankara'da nispi nem oranları düşüktür. Genel olarak Ankara-Türkiye'de Azor kaynaklı YB merkezi ile güneydoğudan sokulan Basra Alçak Basıncı hâkim olmaktadır (Koçman, 1993). Nispi nem oranlarının azaldığı sıcak dönemde rüzgâr hızları da soğuk döneme göre düşüktür.

Sıcak dönemde yapılan ölçümlerde Ankara'daki yerel basınç durumu aylara göre farklılık göstermiştir. Hem gece hem de gündüz ölçümlerinde Ankara'da nisan, mayıs ve eylül aylarında AB şartları hâkimken, temmuz ayında $\mathrm{YB}$, ağustostaki ölçüm ise $\mathrm{AB}-\mathrm{YB}$ arasında gerçekleştirilmiştir. Haziran ayında gündüz ölçümünde $\mathrm{YB}$, gece ölçümünde ise basın gradyanı zayıftır ve hâkim bir basınç yapısı belirgin değildir. Nisan, mayıs ve eylül ayları ölçümleri, ŞIA gelişimi için ideal şartlar sunmazken, ağustos ölçümü yarı ideal, temmuz ölçümü ise ideal ŞIA şartlarında yapılmıştır. Haziran ayı gece ölçümlerinde yar1-ideal, gündüz ölçümünde ise ideal şartlar yaşanmıştır. ŞIA gelişimi için ideal şartların oluşmadığı aylarda, Ankara'daki istasyonlarda ölçülen mutlak basınç değerlerinde fark da yüksektir. Sıcak dönemde yapılan gece ölçümlerinin haziran ve mayıs ayı dışındakiler açık gökyüzü koşullarında yapılmış, mayıs ayındaki ölçüm ise yağışlı bir anda yapılmıştır. Gündüz ölçümlerinde ise temmuz ve ağustos ayı ölçümü açık gökyüzü koşullarında, diğer ölçümler ise az bulutlu gökyüzü şartlarında yapılmıştır (Çizelge 6). 
Çizelge 6. Sıcak dönem ölçümleri esnasında Ankara'da hava koşulları

\begin{tabular}{|c|c|c|c|c|c|c|c|}
\hline & Ay & $\begin{array}{l}\text { Hakim } \\
\text { Basinç }\end{array}$ & Hava Koşulu (Gün) & $\begin{array}{l}\text { Hava Koşulu (Ölçüm } \\
\text { Saati) }\end{array}$ & $\begin{array}{l}\text { ŞIA } \\
\text { Durumu }\end{array}$ & $\begin{array}{l}\text { Basınç } \\
\text { Durumu (mb) }\end{array}$ & $\begin{array}{l}\text { Nispi Nem } \\
\text { Durumu (\%) }\end{array}$ \\
\hline \multirow{6}{*}{ שّ } & Nisan & $\overline{\mathrm{AB}}$ & Parçalı bulutlu & Az bulutlu & İdeal değil & $918-933$ & $49-66$ \\
\hline & Mayıs & $\mathrm{AB}$ & Parçalı, çok bulutlu & Gök gürültülü sağanak & İdeal değil & $924-936$ & $70-92$ \\
\hline & Haziran & AB-YB & Parçalı bulutlu & Az bulutlu & Yarı ideal & $923-933$ & $36-65$ \\
\hline & Temmuz & YB & Az bulutlu & Açık & İdeal & $922-931$ & $20-35$ \\
\hline & Ağustos & AB-YB & Az bulutlu, açık & Açık & Yarı ideal & $931-939$ & $30-42$ \\
\hline & Eylül & $\mathrm{AB}$ & Parçalı bulutlu & Açık & İdeal değil & $923-938$ & $38-52$ \\
\hline \multirow{6}{*}{ 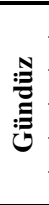 } & Nisan & $\mathrm{AB}$ & Parçalı bulutlu & Az bulutlu & İdeal değil & $920-931$ & $44-65$ \\
\hline & Mayis & $\mathrm{AB}$ & Parçalı, çok bulutlu & Az bulutlu & İdeal değil & $925-937$ & $65-97$ \\
\hline & Haziran & YB & Parçalı bulutlu & Az bulutlu & İdeal & 923-933 & $48-62$ \\
\hline & Temmuz & YB & Az bulutlu & Açık & İdeal & $923-933$ & $42-46$ \\
\hline & Ağustos & AB-YB & Az bulutlu, açık & Açık & Yarı ideal & $932-941$ & $47-75$ \\
\hline & Eylül & $\mathrm{AB}$ & Parçalı bulutlu & Az bulutlu & İdeal değil & $927-945$ & $43-65$ \\
\hline
\end{tabular}

Sıcak dönemde yapılan ölçümlerin ortalamaları, genel hava sıcaklığı gidişine uymaktadır. En yüksek sıcaklık ortalaması temmuz, en düşük ise ekim ayında ölçülmüştür. Bu özellik minimum ve maksimum sıcaklıklar da görülmektedir (Çizelge 7).

Ölçümlerde hesaplanan standart sapma değerleri aylara göre farklılık göstermiştir. En yüksek standart sapma değerleri ağustos ayında, en düşük standart sapma değerleri ise gündüz ölçümlerinde temmuz, gece ölçümlerinde ise ağustos ayında hesaplanmıştır (Çizelge 7). Temmuz ayında standart sapmada görülen yüksek değerler, Ankara'daki nispi nem değerlerinin düşük olması ile ilişkilidir (Çizelge 6). Sıcak dönemdeki gece ölçümlerinde sıcaklık genliği $4,7^{\circ} \mathrm{C}$ ile $7,5^{\circ} \mathrm{C}$ arasında değişmiştir. En yüksek sıcaklık genliği haziran ayında, en düşük sıcaklık genliği ise mayıs ayında hesaplanmıştır. Gündüz ölçümlerindeki sıcaklık genliği incelendiğinde en yüksek sıcaklık farkının ağustos ayında, en düşük genliğin ise temmuz ayında hesaplandığı görülmektedir. Temmuz ayında sıcaklık genliğindeki düşüş yine ölçümün nem değişkenliğinin düşük olduğu bir zamanda yapılmasından kaynaklanmaktadır (\% 4) (Çizelge 6). ŞIAŞ'ın (genlik) kurak ve sıcak dönemlerde daha etkin olduğu başka şehirlerde de belirlenmiş (Elagib, 2011; Jahangir ve Moghim, 2019; Schatz vd., 2014; Zhou vd., 2014), bu açıdan Ankara da benzer özellikler görülmüş, sıcaklığın düşük olduğu aylarda düşük, yaz aylarında genlik değerleri ile karşılaşılmıştır.

Çizelge 7. Sıcak dönemde gece ölçümlerine ait tanımlayıcı istatistikler

\begin{tabular}{|c|c|c|c|c|c|c|c|}
\hline & Değişken & Nisan & Mayıs & Haziran. & Temmuz & Ă̆ustos & Eylül \\
\hline \multirow{5}{*}{ تِّ } & O. S. & 12.92 & 15.33 & 18.06 & 31.68 & 23.85 & 18.52 \\
\hline & Mak. S. & 16.39 & 18.25 & 20.56 & 35.50 & 27.45 & 21.66 \\
\hline & Min. S. & 9.62 & 13.57 & 13.07 & 28.62 & 21.64 & 16.26 \\
\hline & Std. S. & 1.35 & 0.93 & 1.67 & 1.39 & 1.32 & 1.31 \\
\hline & Genlik & 6.77 & 4.68 & 7.49 & 6.88 & 5.81 & 5.40 \\
\hline \multirow{5}{*}{ تِ } & O. S. & 8.82 & 17.18 & 17.77 & 27.81 & 19.65 & 15.74 \\
\hline & Mak. S. & 11.85 & 19.39 & 19.97 & 29.83 & 22.48 & 18.13 \\
\hline & Min. S. & 6.28 & 14.82 & 14.59 & 26.45 & 16.00 & 13.86 \\
\hline & Std. S. & 1.28 & 0.81 & 1.31 & 0.64 & 1.12 & 0.74 \\
\hline & Genlik & 5.57 & 4.57 & 5.38 & 3.38 & 6.48 & 4.27 \\
\hline
\end{tabular}

Not: OS- Ortalama sıcaklık, Mak. S.-Maksimum sıcaklık, Min. S.-Minimum sıcaklığı ifade eder.

Sıcak dönem gece ölçümlerinde, ölçüm hattının kuzeyindeki falez (Şekil 7), Yozgat Bulvarı ortalarında, oluşmuştur. Falezin sıcaklık farkı $3-4{ }^{\circ} \mathrm{C}$ civarındadır. Gündüz ölçümlerinde ise falez çok 
belirgin değildir. Yozgat Bulvarı'ndan sonra sıcaklıklar düşmekte, Yükseltepe Kavşağı'nda oluşan falezin değeri $1{ }^{\circ} \mathrm{C}$ civarında olmaktadır. Falezin oluşmasında yükselti de etkili olmaktadır. Harun Reşit Caddesi ile Yozgat Bulvarı, bir boyun noktasının (Yükseltepe Kavşağı) kuzeyi ve güneyini oluşturan caddeler şeklindedir. Kavşaktaki yükselti çevreye göre daha fazla olduğundan sicaklıklar yükseltiden de etkilenmektedir. Bu nokta şehirsel alanın da başladığı, yapılaşmanın yoğunlaştığı bir yerdir. Burada oluşan falez de şehir-kır sınırı açısından önemlidir (Oke, 2002) ve şehir planlamalarında hesaba katılması gereken yerlerdir (Yamashita, 1996). Falezden sonra sicaklıklar, Harun Reşit Caddesi'nden sonra tekrar yükselmekte ve Etlik Caddesi'nde Yozgat Bulvarı'ndaki sıcaklığı ancak geçebilmektedir.

Etlik Caddesi’nde tüm aylarındaki sıcaklıklar hem gece hem de gündüz ölçümlerinde Yozgat Bulvarı'na göre 3-4 ${ }^{\circ} \mathrm{C}$ daha yüksek olmasına rağmen bu caddedeki sıcaklıklar şehrin platosu özelliği göstermekte ve değişkenlik göstermektedir. Bunda, soğuk dönemde olduğu caddeyi kesen yan yolların etkisi görülmekte, kanyon etkisi kesintiye uğramakta, sıcaklıklar birbiri ardına yükselmekte ve düşmektedir. Etlik Caddesi çıkışından sonra GATA Kavşağı ve Ankara Çayı'na yaklaşılır. Bu alana geçişte sıcaklıklar düşmektedir $\left(1.5-2{ }^{\circ} \mathrm{C}\right)$. Bu sahadaki sıcaklık düşüşü temmuz ayı gece ölçümünde 5 ${ }^{\circ} \mathrm{C}$ 'a varmaktadır. $\mathrm{Bu}$ saha çevresindeki boşluklar ve yeşil alanlar nedeniyle daha serin özellik göstermektedir (Chen ve Wong, 2006). Ankara çayından sonra sıcaklıklar yükselmeye başlamakta, 1011 Kavşă̆ı'nda Ankara Çayı'na ve İller Bankası Caddesi'ne göre bir sıcaklık tepesi özelliği kazanmaktadır. İller Bankası Caddesi'nden güneye doğru sıcaklıklar düşmekte, bunda yeşil alanların ve şehir içi boşlukların etkisi bulunmaktadır. Hem gece hem de gündüz ölçümlerinde İller Bankası Caddesi'nden Çankırı Caddesi'ne girişte sıcaklıklar aniden yükselmektedir. Bu artış nisan, temmuz ve eylülde 2-3 ${ }^{\circ} \mathrm{C}$ 'a ulaşmaktadır.

Gündüz ölçümlerinde Çankırı Caddesi’ndeki sıcaklıklar Etlik Caddesi ile benzer özellikler göstermekte, bazı aylarda düşebilmektedir (temmuz ve ağustos). Bu cadde, GGO değerlerinin düşük olduğu bir sahadır. Bu nedenler güneş doğuşundan belli bir süre sonra aydınlanmakta ve direkt güneş 1şığı alabilmektedir. Bu da gündüzleri geç ssınmasına neden olmaktadır. Caddenin uzanışı da bunda etkili olmaktadır. Kuzey-güney uzanışlı bu caddede binalar sürekli bir şehir yapısı özelliği gösterecek şekilde yanyana inşa edilmiştir. Bu da caddenin tam bir şehir kanyonu özelliği kazanmasına neden olmaktadır. Soğuk dönemde Ulus civarında oluşan sıcaklık zirvesi, sıcak dönemde de oluşmakta, Kızılay'a göre hem gece hem de gündüzleri daha yüksek sıcaklık değerleri ölçülmektedir. Ulus, trafiğin, ticaretin ve yapılaşmanın yoğun olduğu, şehrin merkezlerinden biridir. Burada oluşan zirve, geceleri tam Ulus Caddesi üzerinde oluşurken gündüzleri Gençlik Parkı'na doğru kayma göstermektedir. Bunda rüzgârın etkili olduğu düşünülmektedir. Gençlik Parkı ve Adliye Caddesi'nde trafik yoğun olmasına rağmen, yapılaşma düşük, GGO değerleri yüksektir. Bu nedenle gündüz ölçümlerimde sıcaklıklar daha yüksektir. Bu sahadaki sıcaklıklar bazı aylarda Ulus'a benzer şekilde devam ederken, bazı aylarda aniden düşmektedir (nisan ve mayıs). Bu duruma hava durumunun etki ettiği, yağışılı günlerde burada sıcaklıkların daha düşük olduğu anlaşılmaktadır (Çizelge 6). 

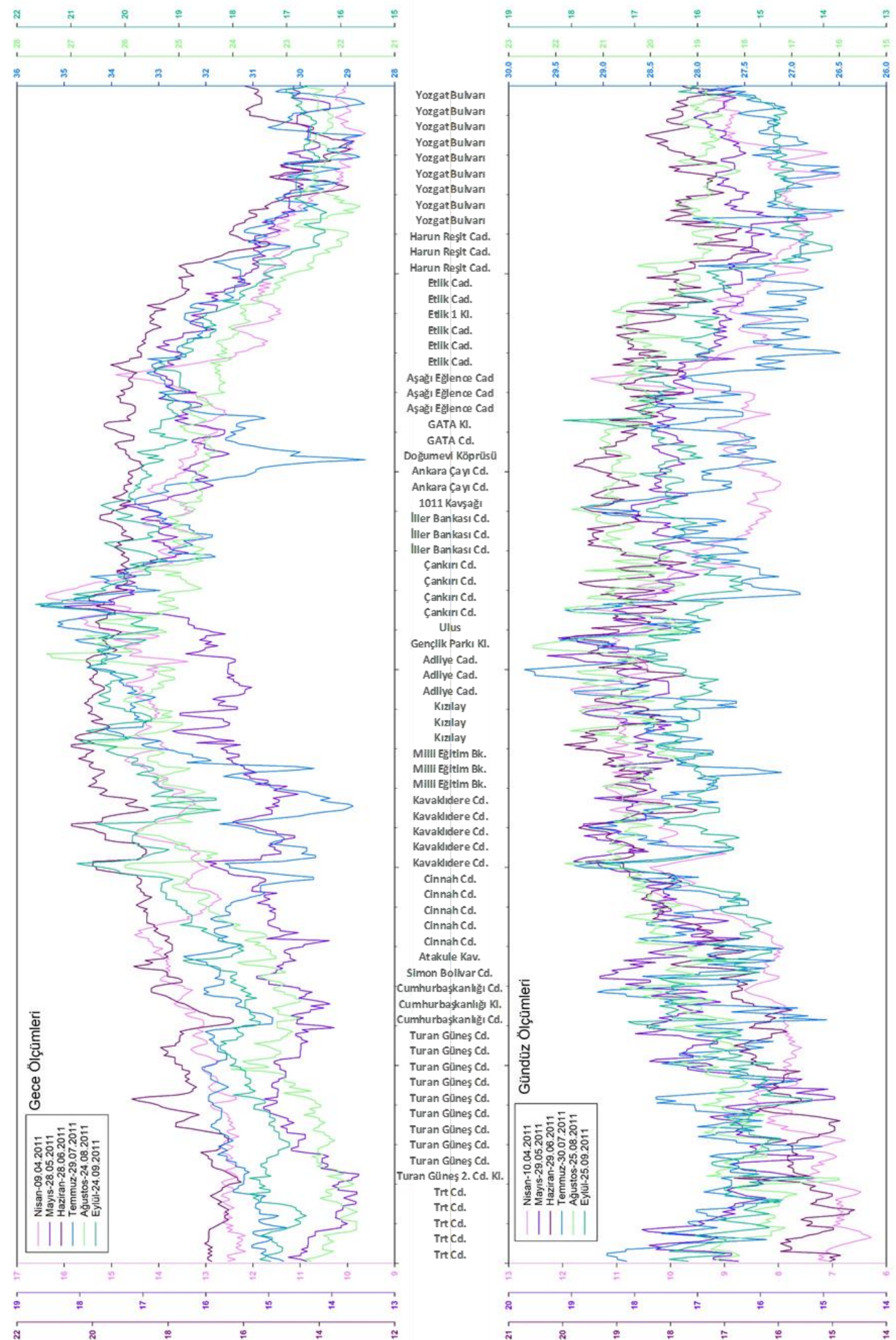

Şekil 7. Sıcak dönem ölçüm sonuçları (Düşey ölçeklerde sıcaklıklar ${ }^{\circ} \mathrm{C}^{\prime}$ tır ve her ay için ayrı renkte hazrlanmıştır). 
Adliye Caddesi'nden sonra Sıhhiye ve Kızılay'a ulaşılmakta, bu sahada sıcaklıklar genel olarak Ulus'a benzer özellikler göstermekte, zirve özelliğine sahip olmakla beraber haziran-eylül aylarında Ulus'tan daha serin ama ikinci bir zirve özelliği sunmaktadır. Bu zirve gece ölçümlerinde daha belirgin bir şekilde görülmekte olsa da soğuk dönemde olduğu gibi Ulus zirvesi gibi yüksek sıcaklık farkı göstermemektedir. Millî Eğitim Bakanlığı Caddesi'nde sıcaklar düşmeye başlamakta, TBMM önünden geçilirken yeşil alanların etkisiyle sıcaklıklar daha da düşmekte, Kavaklıdere Caddesi'ndeki kavşaklarda ise sıcaklıkların arttığı anlaşılmaktadır. Yeşil alanların UHI şiddetini azalttığı bilinen bir durumdur (Doick, Peace ve Hutchings, 2014; Zhou vd., 2015) ve TBMM çevresinde de bu etki görülmektedir. Kavaklıdere caddesinde kavşaklar ile cadde arasındaki sıcaklık farkının oluşmasında, kavşakların geçişinde alt geçit kullanılması etkili olmaktadır. Burada yer alan yollarda, kavşakların geçişin alt geçitlerden yapılmakta, rüzgâr etkisi ortadan kalkmakta, bu da sıcak dönem gece ölçümlerde yüksek değerler ölçülmesine neden olmaktadır. Bunun benzeri Kavaklıdere-Cinnah Caddesi arasındaki Akay Alt Geçidi'nde de görülmektedir. Cinnah Caddesi çıkılırken sıcaklıklar düşmeye başlamakta ve değişkenlik göstermeye başlamaktadır. Atakule kavşağında sıcaklıklar aniden yükselmekte, buradaki trafik yoğunluğu ve kirletici miktarına bağlı sıcaklık artışı görülmekte bu durum hem gece hem de gündüz ölçümlerine yansımaktadır. Cumhurbaşkanlığı Caddesi çevresinde sıcaklıklarda düşüş görülmekte ve bir sıcaklık çukuru meydana gelmektedir. Turan Güneş Caddesi'ne geçişte tekrar yükselen sıcaklıklar, caddede güney yönünde ilerledikçe yükseltiye bağlı olarak düşmekte, gündüz ölçümlerinde sıcaklıklar yüksek seviyede devam etmektedir.

Şehrin güney falezi hem gündüz hem de gece ölçümlerinde kuzeyde olduğu gibi belirgin değildir. Cinnah Caddesi'nden sonra sıcaklıklar düşmeye başlamakta, bu düşüş Turan Güneş Bulvarı ortalarına kadar devam etmektedir. Bu sahadaki sıcaklık düşüşü, genel olarak yükselti ile ilişkilidir. Turan Güneş Bulvarı geçildikten sonra hem gündüz hem de geceleri sıcaklıklar yükselmektedir. Bu saha, GGO değerlerinin oldukça yüksek olduğu, yüksek bir plato (morfolojik) olma özelliğindedir. Sıcaklık artışı kırsal alana doğru daha da artmakta, nisan ve haziran aylarında gündüz sıcaklıkları düşmeye devam etmektedir.

\section{3. Ölçümlerin Modellenmesi}

Çalışmada ölçüm sonuçları ile yükselti, gök görüş oranı ve şehir merkezine uzaklık değişkenleri arasında ilişki aranmış ve bu ilişkilere bağlı modeller kurulmaya çalışılmıştır. Çoklu regresyon kullanılarak kurulan modellerin bir kısmı istatistiksel olarak anlamlıyken bir kısmı istatistiksel olarak anlamlı değildir. Modellerin belirleme katsayısı yani $\mathrm{R}^{2}$ değerleri incelendiğinde, 0,01 ile 0,90 arasında değiştiği görülmektedir (Çizelge 8). Model sonuçlarına gece ve gündüz olarak ayrı ayrı bakıldığında, 6 geceye ait model belirleme katsayısı gündüzden yüksek çıkmıştır. Ayrıca model belirleme katsayılarının gece ve gündüzde birbirine yaklaşık değerde çıktı̆̆ 1 görülmektedir. Sadece ocak ayı katsayılarında gündüz ölçümüne ait model belirleme katsayısı geceye oranla çok düşük çıkmıştır. Bunun da ocak ayındaki alçak basınçtan kaynaklandığı anlaşılmıştır (Çizelge 4). 
Çizelge 8. Ölçümlerin modellenmesi sonucu elde edilen gece ve gündüz ölçümlerine ait belirleme katsayıları $\left(\mathrm{R}^{2}\right)$ ve bunlara ilişkin hipotez testi sonuçları (P değerleri).

\begin{tabular}{lllllllllllll}
\hline & Ocak & Şubat & Mart & Nisan & Mayıs & Haziran & Temmuz & Ağustos & Eylül & Ekim & Kasım & Aralık \\
\hline Gündüz & 0.520 & 0.468 & 0.677 & 0.629 & 0.564 & 0.785 & 0.237 & 0.761 & 0.426 & 0.606 & 0.845 & 0.864 \\
\hline P değeri & 0.000 & 0.000 & 0.000 & 0.000 & 0.000 & 0.000 & 0.000 & 0.000 & 0.000 & 0.000 & 0.000 & 0.000 \\
\hline Gece & 0.013 & 0.385 & 0.714 & 0.699 & 0.660 & 0.768 & 0.337 & 0.881 & 0.854 & 0.816 & 0.658 & 0.853 \\
\hline P Değeri & 0.054 & 0.000 & 0.000 & 0.000 & 0.000 & 0.000 & 0.000 & 0.000 & 0.000 & 0.000 & 0.000 & 0.000
\end{tabular}

Kurulan modellerin ocak ayı gündüz ölçümü haricinde tamamı istatistiksel olarak anlamlı çıkmıştır. Bunda modelde kullanılan ölçüm sayısının (n=595) yüksek olması etkili olmuştur.

Çoklu regresyon sonuçlarının regresyon katsayıları incelendiğinde, değişkenler açısından farlı etkileme oranları ve yönleri ile karşılaşılmaktadır. Şehirsel alanlarda sıcaklık ile GGO arasında ilişkiler bulunduğu, bu ilişkilerin dar caddelerde daha yüksek olduğu bilinmektedir (Ibrahim vd., 2011). Ayrıca GGO’nun yanında gökyüzü açıklık yönünün (Qaid vd., 2018) ve cadde uzanış doğrultusunun da sıcaklık üzerine etkisi bulunmaktadır (Ahmadi Venhari vd., 2019). Model sonuçlarına göre GGO'ya ait gece katsayıları incelendiğinde (Şekil 8), değerlerin -2,74 ile 1,44 arasında değiştiği görülmektedir. Gündüz ölçümlerindeki gök görüş oranına ait katsayılar incelendiğinde, değerlerin -1,62 ile 2,31 arasında değiştiği, ocak, şubat, ağustos ve aralık ayı gündüz ölçümlerinde katsayıları negatif çıktığı belirlenmiştir (Şekil 8). Gündüz ölçümlerinde GGO değeri ile sıcaklıklar arasında mevsimsel bir ilişki görülmüş, genel olarak soğuk dönemde GGO-sıcaklık arasında negatif, sıcak dönemde ise pozitif bir ilişki olduğu görülmüş̧ür. Bunun da güneş doğuşundan ölçüm saatine kadar geçen süre ile ilişkili olduğu anlaşılmakta, sürenin artması durumda ilişkinin pozitif yöne doğru değişmekte ve teorik bilgi ile örtüşmektedir. Gece ölçümlerinde ise genel olarak soğuk dönemde GGO-sıcaklık arasında pozitif, sıcak dönemde ise etkisiz ya da negatif ilişkinin olduğu görülmektedir. Bu durumunda oluşmasında gündüz ölçümlerine benzer şekilde güneş batışından sonra geçen sürenin etkili olduğu, süre arttıkça GGO ile sıcaklığın pozitif, kısaldığında ise negatif bir ilişkiye sahip olduğu anlaşılmaktadır (Çizelge 3). 


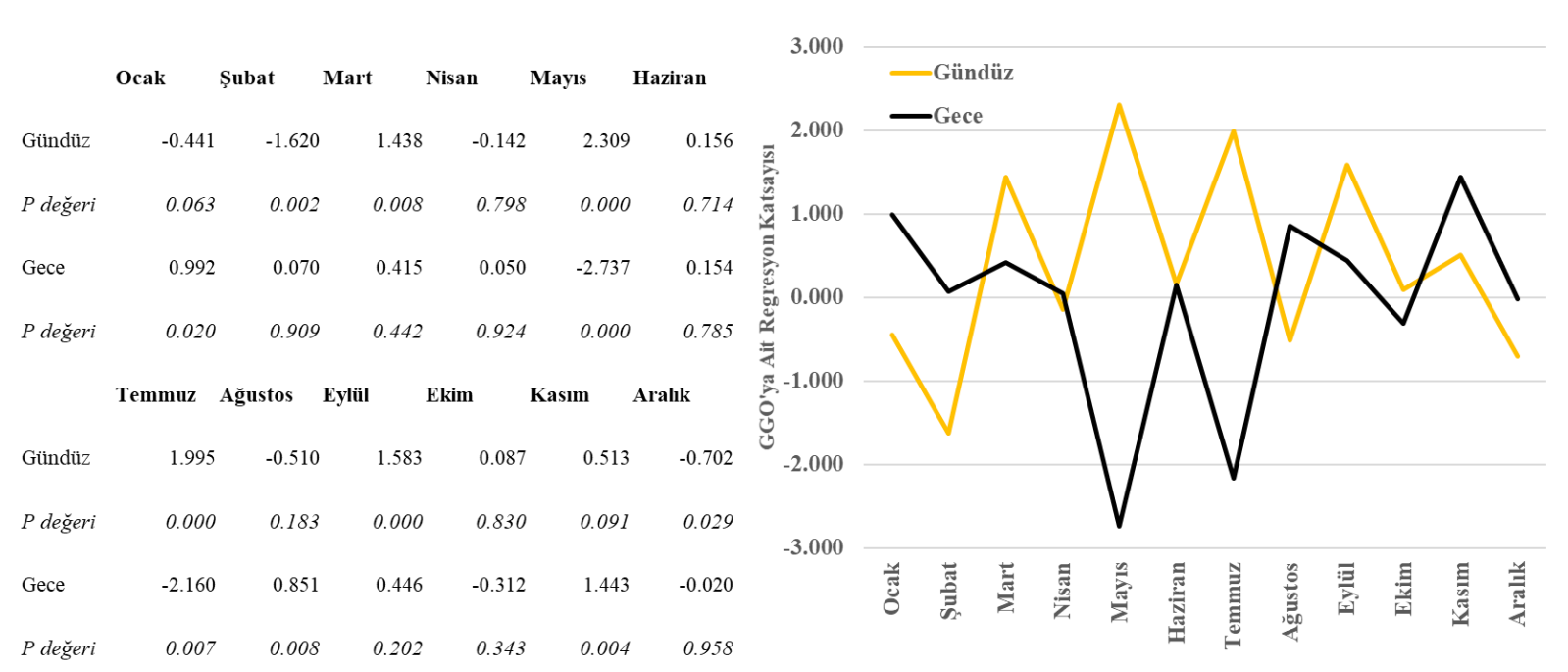

Şekil 8. Gök görüş oranlarına (GGO) ait gece ve gündüz regresyon katsayıları ve hipotez testi sonuçları (p değeri) tablosu ve bu değerlerin y1l içindeki değişimi (Sağdaki grafik).

Şehir merkezine (Opera Köprüsü’ne) uzaklık, teorik olarak sıcaklık ile ters orantı göstermekte, merkeze yaklaştıkça sıcaklıkta da artışlar gözlenmektedir (Oke, 1973, 2002; Singh, Kikon ve Verma, 2017). Şehirsel alanın büyümesi ŞIAŞ’nın da büyümesine neden olmakta, büyüme yönü ve niteliği, ŞIA'nın merkezinde kaymalara neden olabilmektedir (Qiao vd., 2014; Streutker, 2002). Modelleme sonuçlarında şehir merkezine uzaklık değişkeninin katsayıları incelendiğinde, merkeze negatif değerlerle karşılaşılmış ve merkezden uzaklaştıkça sıcaklığın düştüğü anlaşılmıştır. Sadece ocak ayı gece-gündüz ve şubat ayı gündüz ölçümün ait katsayılar pozitif çıkmış, merkezden uzaklaştıkça sıcaklığın arttığı gibi bir sonuç görülmüştür. Bunun nedeni, ocak ayı ölçümündeki hava koşullarıdır. Bu aydaki ölçüm alçak basınç dönemine gelmiş, yer koşullarının sıcaklığa etkisi minimum düzeyde kalmıştır. Model sonuçları incelendiğinde (ocak ayı hariç) geceleri şehir merkezinden uzaklaştıkça, her 1 kilometrede sıcaklığın yaklaşık olarak $0,1{ }^{\circ} \mathrm{C}$ ile $0,6{ }^{\circ} \mathrm{C}$ arasında düştüğü anlaşılmıştır. Bu değerlerin yıl içindeki değişimine bakıldığında ise, şehir merkezine yaklaştıkça yaz aylarındaki sıcaklık değişimi düşmekte (0'a yaklaşmakta), kış aylarında ise yükselmektedir (ocak ve şubat aylarındaki pozitif değerler hariç). 


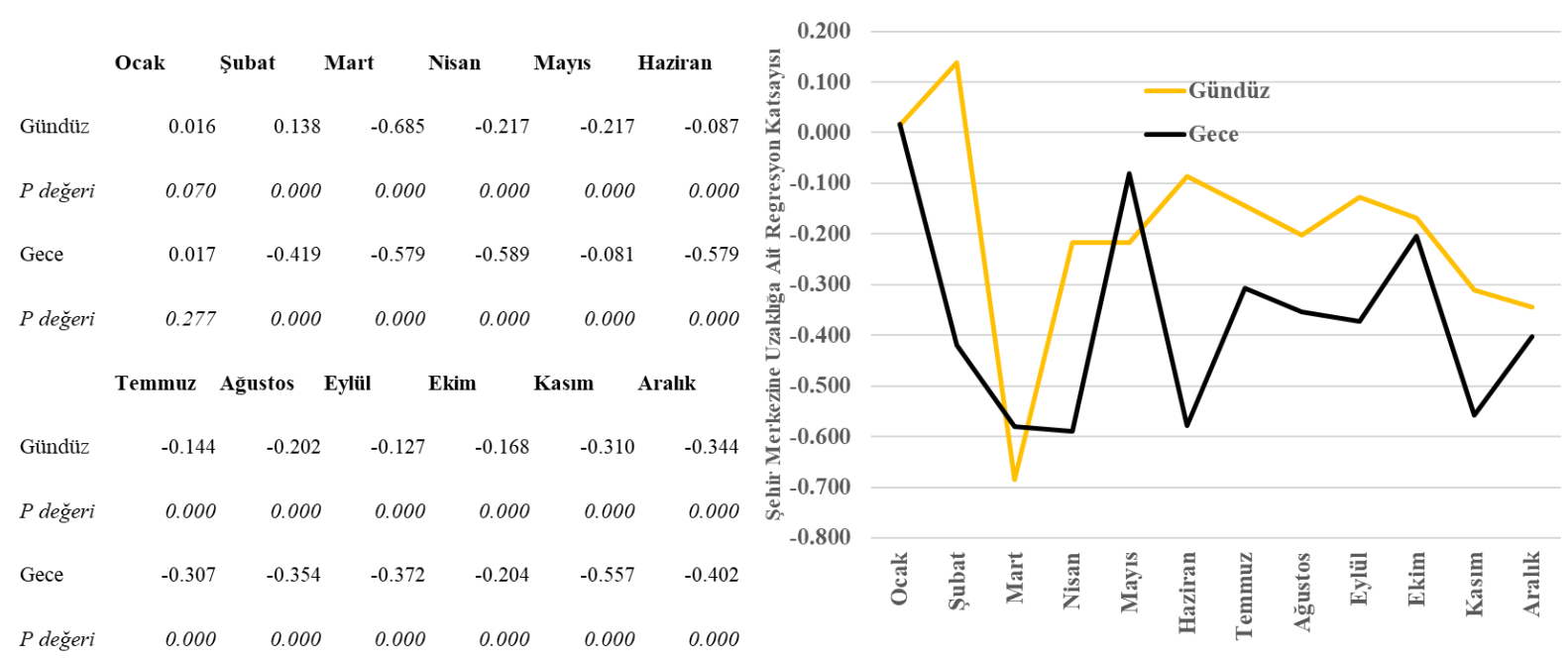

Şekil 9. Şehir Merkezine Uzaklığa Ait Gece ve Gündüz Regresyon Katsayıları, Hipotez Testi Sonuçları (P değeri) ve Yı1 İçindeki Değişimi (Sağdaki grafik)

Modelde kullanılan yükselti değişkeni, teorik olarak sıcaklıkla ters orantılı bir değişkendir. Yükselti arttıkça sıcaklık teorik olarak düşmektedir (Erol, 1985, s. 72). Bunun Türkiye'de mevsimlere göre değiştiği (Akman, 1990, s. 260). Rölyef, ŞIA oluşumunu arazi kullanımına göre daha fazla etkileyebilmektedir (Bokwa vd., 2015). Ayrıca yağışlı dönemlerde yükselti-sıcaklık ilişkisi bilinenin tersi yönde işleyebilmektedir (Mathew, Khandelwal ve Kaul, 2016). Model sonuçlarına göre yükselti değişkenine ait katsayıların 9'u pozitif (gündüz 3, gece 6) geri kalanları ise negatif çıkmıştır (Şekil 10). Yani gece yapılan ölçümlerde sıcaklık, 6 ay teorik bilgiye göre hareket ederken, 6 ay tam tersi yönde etkili olmuştur. Bu pozitif yönde etkileme durumu genel olarak soğuk dönemde daha belirgindir. Bu da soğuk dönemdeki Ankara şehrinde geceleri meydana gelen terselme ile ilişkilidir (Çiçek, 2005).
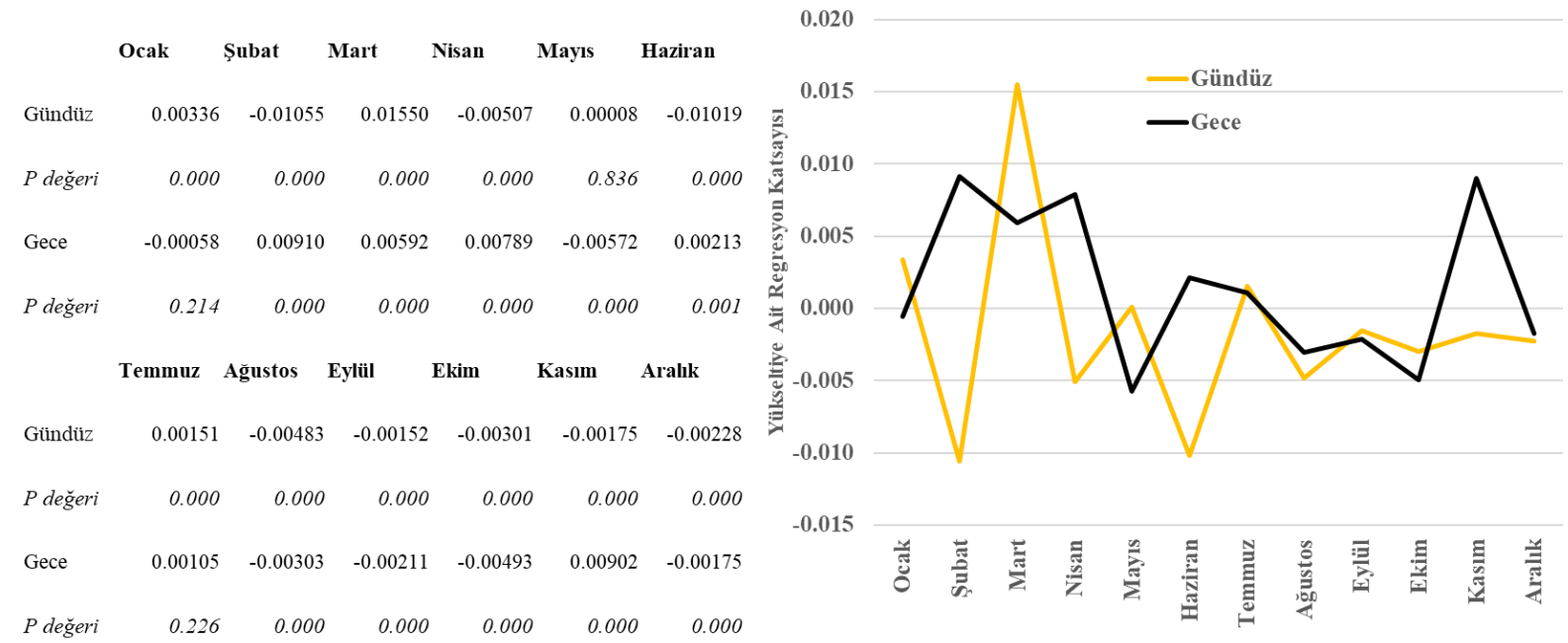

Şekil 10. Yükseltiye Ait Gece ve Gündüz Regresyon Katsayıları, Hipotez Testi Sonuçları (P değeri) ve Yı1 İçindeki Değişimi (Sağdaki grafik). 
Mart ayı gündüz ölçümünde yükselti ile sıcaklık arasında çok yüksek pozitif regresyon katsayısı belirlenmiş, bunun hava durumu ile ilişkisi belirlenememiştir. Şubat ve haziran aylarında belirlenen negatif regresyon katsayıları da oldukça yüksektir. Bu aylarda ölçümler, hava açık-parçalı bulutlu, ideal ŞIA koşullarında yapılmıştır (Çizelge 4, Çizelge 6).

\section{Sonuç}

Yapılan analizler ve karşılaştırmalar neticesinde Ankara şehri için aşağıdaki sonuçlara ulaşı1mıştır.

a) Ankara'da ŞIA'nın zirve kısmı tek bir yer değil, değişken özelliktedir ve Ulus ve Kızılay Caddesi arasında oluşmaktadır. Ulus ve Kızılay'da oluşan zirve, Adliye Caddesi ve çevresindeki şehir içi boşluklar ve yeşil alanlarla kesintiye uğramaktadır. Zirve soğuk dönemde Kızılay’da oluşabilirken, sıcak dönemde ölçüm yapılan zamanlarda Ulus'ta oluşmuştur. Ankara ŞıA'nın falezi, zamana bağlı olarak yer değiştirse de ölçüm yapılan güzergâhta, kuzeyde Yükseltepe Kavşağı ve çevresinde, güneyde ise Turan Güneş Bulvarı'nda oluşmaktadır. ŞIA'nın kuzey platosu, Çankırı Caddesi ile Ayvalı Pazar Yeri arasında, güney platosu ise MEB Caddesi ile Turan Güneş Bulvarı arasında uzanmaktadır. Plato boyunca, kavşaklar ile çevresine göre yüksek yoğunluklu şehirsel alanlar sıcaklık tepesi özelliği göstermektedir. Plato üzerindeki yeşil alanlar, çevresine göre serin özellik göstermekte ve serin sıcaklık çukurlarını meydana getirmektedir. ŞIAŞ'ın şekil ögeleri gece ölçümlerinde ve sıcak dönemde daha belirgindir. Soğuk dönemde, AB zamanlarında ve yağışlı hava koşullarında ŞIAŞ’ın şekil ögeleri ortadan kalkmaktadır.

b) Şehirsel alanda sıcaklıklar ile yükselti arasındaki ilişki özellikle Ankara şehri için gece ve gündüz ve aylar arasında değişmektedir. Soğuk dönem gece ölçümlerinde terselme etkisiyle yükseltisıcaklık ilişkisi terse dönmekte, yükseldikçe sıcaklık artmaktadır. Sıcak gece ölçümleri ve tüm gündüz ölçümlerinde yükseltiye bağlı sıcaklık düşüşü görülmekte, sıcaklık düşüş değer hava durumu ve meteorolojik özelliklere göre değişmektedir.

c) Ankara'da GGO değerleri ile sıcaklıklar ölçüm zamanına ve mevsime göre değişmektedir. Geceleri GGO ile sıcaklık arasında sıcak dönemde negatif, soğuk dönemde pozitif ilişki, gündüzleri ise GGO-sıcaklık arasında soğuk dönemde negatif, sıcak dönemde pozitif ilişki bulunmaktadır. Bu durum güneş doğuşundan ölçüm zamanına kadar geçen süre ile ilişkilidir. Gündüzleri ısınma süresi artığında GGO-sıcaklık ilişkisi pozitif ilişkiye sahip olmaktadır. Geceleri ise soğuma süresi (radyasyon) uzadığında pozitif ilişki görülmekte, bu durum teorik bilgi ile karşıtlık oluşturmaktadır. Bu karşıtlığın oluşmasında, ölçüm hattının heterojen bir arazi kullanımına sahip olması etkili olmaktadır

d) Ankara'da şehir merkezinden uzaklaştıkça sıcaklıklar hem gece hem de gündüzleri azalmaktadır. $\mathrm{Bu}$ düşüş ortalana olarak geceleri her 1 kilometrede $0,4{ }^{\circ} \mathrm{C}$, gündüzleri ise $0,2{ }^{\circ} \mathrm{C}$ civarındadır.

e) Ankara'da gece ölçümlerinde belirlenen ŞIAŞ (genlik), gündüz ölçümlerinde belirlenen değerden yüksektir. Benzer şekilde, sıcak dönemde ölçülen ŞıAŞ soğuk döneme göre yüksektir. 
f) Ölçümler neticesinde, şehir içi arazi kullanım durumunun sıcaklığa durumuna etki ettiği görülmektedir. GATA ve Adliye Caddesi ile TBMM çevresinde şehir içi boşluk alanlar ve yeşil alanlar bulunması nedeniyle sıcaklıklar daha düşüktür. Kuğulu Parkı çevresinde de sıcaklıklar düşmekte, bunda hem yeşil alan etkisi hem de Kuğulu havuzunun etkisi bulunmaktadır. Kavşaklar trafik yoğunluğu nedeniyle daha sıcak yerler özelliği göstermektedir. Sürekli şehir yapısı özelliği gösteren caddelerdeki sıcaklıklar daha yüksek ölçülmüş, buralar şehir kanyonları olarak karşımıza çıkmıştır (Çankırı ve Kızılay Caddesi). Kanyonları kesen yan yollar olduğunda, sıcaklıklar düşebilmekte, kanyon etkisi kesintiye uğramaktadır. 
Atıf: Yılmaz, E. (2019). Urban Heat Island in Ankara with Travers, Coğrafi Bilimler Dergisi/Turkish Journal of Geographical Sciences, 17(2), 281-317, doi: 10.33688/aucbd.600933.

\begin{tabular}{ccc} 
Coğrafi Bilimler Dergisi & Cografi \\
Bilimler & Dergisi \\
\hline
\end{tabular}

\section{Urban Heat Island in Ankara with Travers}

Erkan Y1lmaz*a

\section{EXTENDED ABSTRACT}

\section{Introduction}

Ankara is a city with semi-arid climate that is located in the Central Anatolia Region at an average elevation about $850 \mathrm{~m}$, approximately $40^{\circ}$ latitudes. Topographically, Ankara is situated in a basin closed by three sides making it more vulnerable to adverse of UHI. The air pollution on the city in 1970s is important showed how such adverse effects could create an bad environment conditions (Akalan, 1984). Although Ankara has been examined by the weather stations data and satellite images, there are not enough stations to enable the morphological units of urban heat island and their changes during the year in detail. The fact that Ankara is built on elevations ranging from $750 \mathrm{~m}$ to $1200 \mathrm{~m}$ also. There are, however, no studies on the effect of elevation for the city. The temperatures decrease from the center towards the periphery and the rate of decrease changes in time. The visibility of the sky leads to different heating conditions and temperatures. Since there is no sufficient information for Ankara in this respect, this study focuses on the following questions:

a) Where are form elements of urban heat island in Ankara? Do these locations change during the year? Are the urban morphological elements always formed in the same manner?

b) Does elevation effect the temperatures in Ankara? And if so, how?

c) What is the correlation between sky visibility and the temperature in Ankara?

d) How does the temperature change as one moves away from the city center of Ankara?

e) When (months) is urban heat island intensity (UHII) higher in Ankara?

f) What is the effect of land use on the temperatures in Ankara?

Mobile measurements and statistical analyses were made and compared with previous studies in order to find answers to questions above.

\section{Data and Methods}

In the study, mobile measurements were applied, and the measurement route composed rural, urban sites and the sites between them having transition features covering Ankara from north to the south. The route contains high and low, north-faced and south-faced, flat and sloped surfaces, and goes

\footnotetext{
* Corresponding Author: eryilmaz@ankara.edu.tr

a Ankara University, Faculty of Languages, History and Geography, Department of Geography, Ankara, Turkey, http://orcid.org/0000-0002-3821-3648
} 
through the city center and its outer border. This line is a different route in land cover and land use, number of floors in a building, distance between the buildings, density of trees on the streets, elevation, aspect, and extension of streets ( Figure 1).

It was considered that measured temperatures in the study were affected by their distance to the city center, elevation and sky view factors (SVF), therefore the effect of these variables on the temperature have been investigated. The multiple regression has been used to determine this effect.

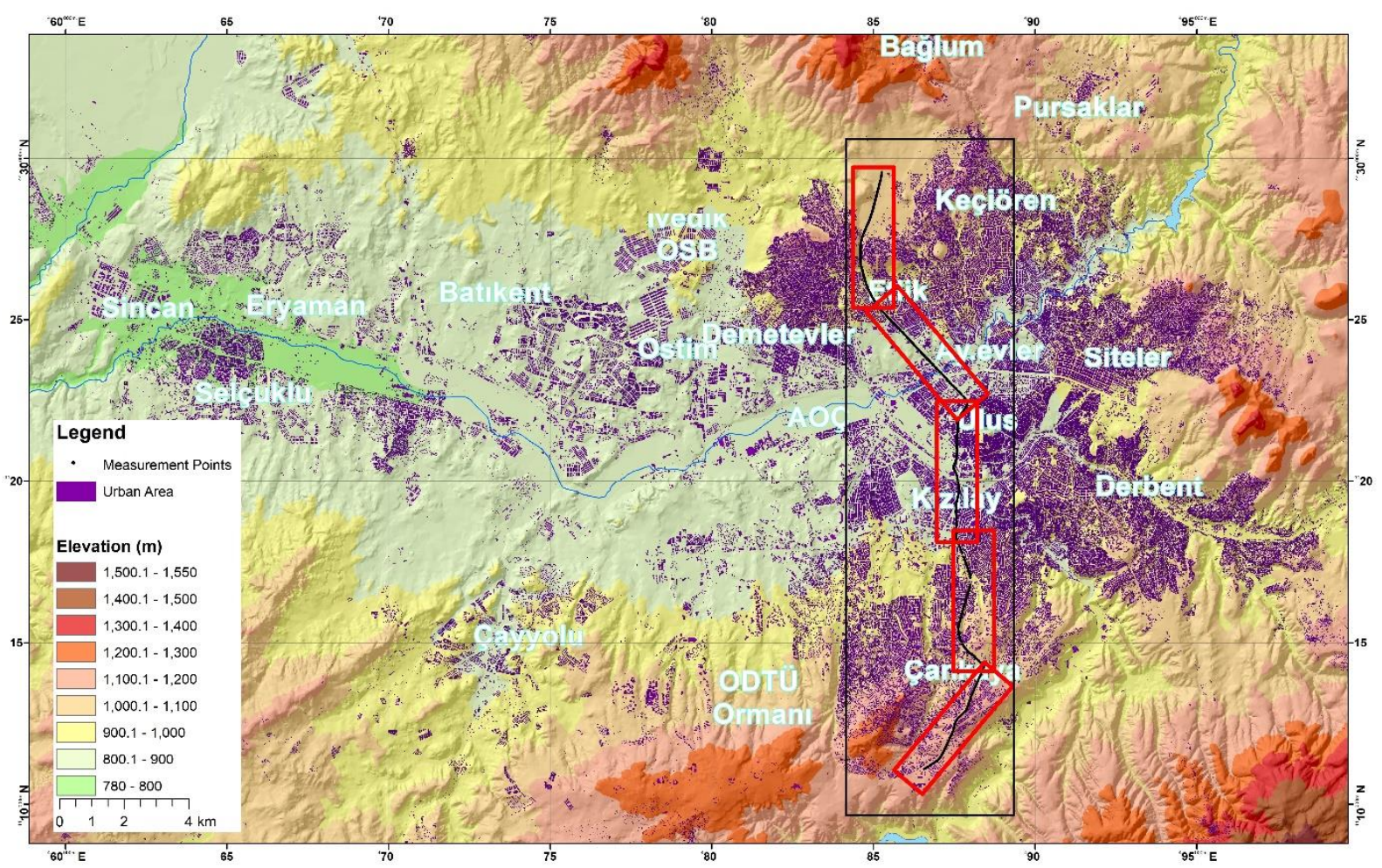

Figure 1. Ankara urban area and travers track line.

\section{Results and Discussion}

Although the northern cliff of UHI was formed to the south of Harun Reşit Street in the night measurements of cold period, the cliff was not completely apparent in January and February (Figure 2). It was formed in the middle of Yozgat Avenue in March. At night measurements, the temperature difference of cliff was approximately $2{ }^{\circ} \mathrm{C}$ whereas it was lower than $1{ }^{\circ} \mathrm{C}$ in day measurements. After the cliff, the section between the Etlik Street and the IIller Bankas1 Street showed a characteristic of plateau of UHI both in day and night measurements. Çankırı Street is a passage from the northern plateau to the city center, and the temperature rises by $1{ }^{\circ} \mathrm{C}$ during that passage. Çankırı Street is an urban canyon because of connected urban structure and suddenly decreased SVF values in this street and there is a busy traffic as it is a major street leading to the city center. The section between Kizılay and Ulus is a site where Adliye Street is located and surrounded by green areas and public buildings. This site has a characteristic of plateau-temperature sink between two peaks and thus, the temperature decreases. There are green areas around TBMM (Parliament) from Kizilay to Kavaklidere. There, the temperatures start to decrease and increase again towards Kavaklıdere. The vicinity of TBMM forms a temperature sink 
which ends at the Kavaklidere Street. Between Kavaklıdere and the Cinnah Street, there are green areas where the embassy buildings and are located, the temperatures decrease again, forming a temperature sink. The southern cliff of UHI was not very obvious in the night measurements. It is formed between TRT and Turan Güneş Street in November and December, and no apparent cliff occurs in other months. It was formed in the middle of Turan Güneş Street February and March in the day measurements. The southern cliff is more sloped than the northern cliff. The temperature drops more slowly. After the cliff, the temperatures raised on the TRT Street both in the day measurements and night measurements, and started to increase towards the rural area. 


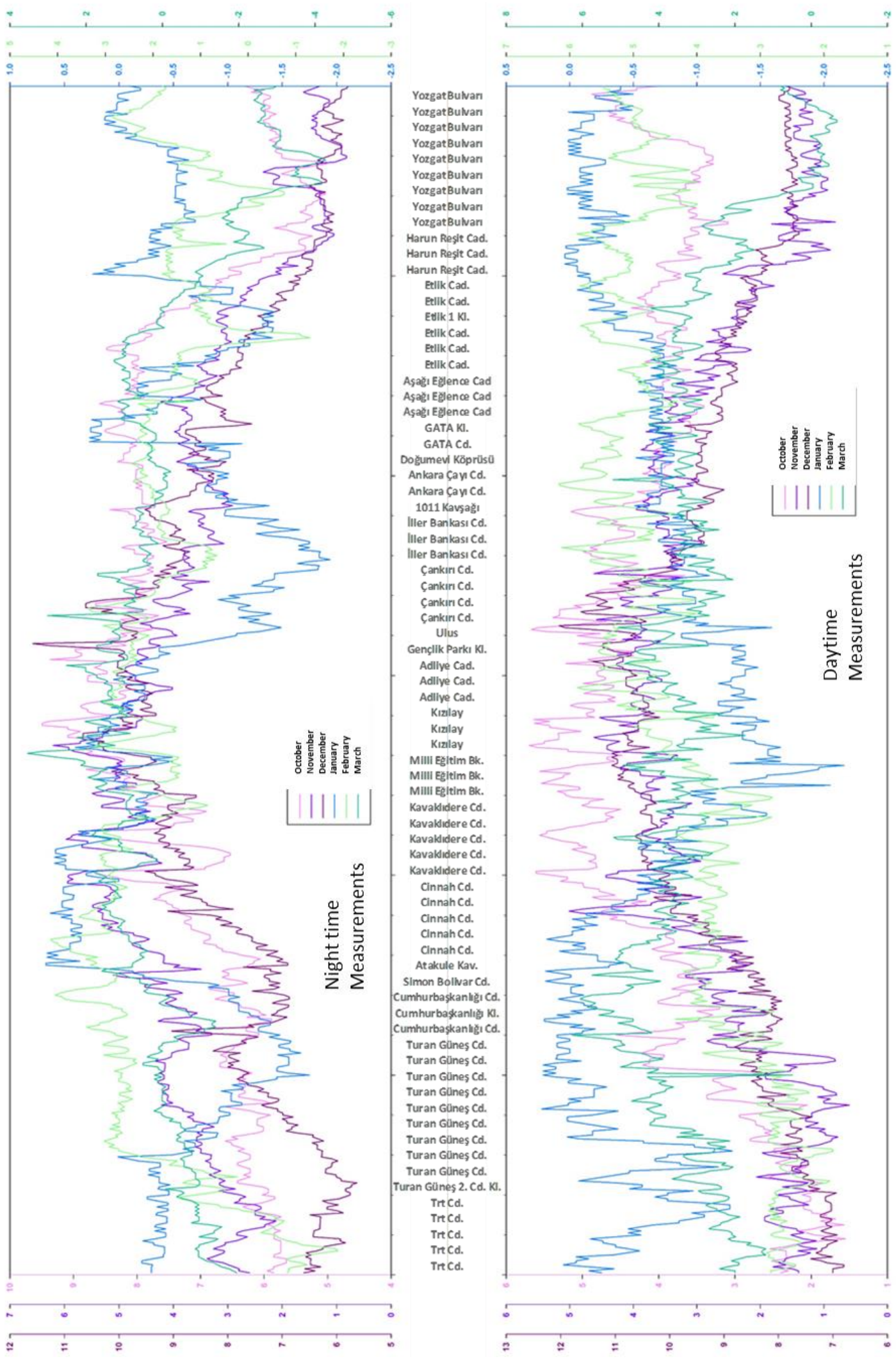

Figure 2. Cold period measurument results 
In the night measurements for hot period, the cliff to the north of the measurement line (Figure 3 ) occurred approximately in the middle of Yozgat Avenue. The temperature difference of cliff is approximately $3-4{ }^{\circ} \mathrm{C}$. The cliff was not very apparent in the day measurements.

Although temperatures on the Etlik Street were higher by $3-4{ }^{\circ} \mathrm{C}$ in all months both day and night measurements compared to Yozgat Avenue, the temperatures of this street have a characteristic of plateau. But the temperature changes in the street is very high.

The peak occurs exactly on the Ulus Street at night and shifts to Gençlik Park during the day most probably due to the wind. Although the traffic is busy on Gençlik Park and Adliye Street, the settlement density is low and SVF are higher. Therefore, temperatures were higher in the day measurements. The temperatures in this site show similarity to those of Ulus in several months, but it decreases suddenly in several months (April and May). It appears that this is affected by the meteorological condition. The temperatures decrease the rainy days especially.

After Adliye Street, there are Sihhiye and Kizllay, and the temperatures are usually similar to those of Ulus in this area; although it has a characteristic of peak, it is cooler than Ulus in JuneSeptember but presents a second peak. This peak was observed more in night measurements but did not show a high temperature difference as Ulus peak as in the cold period. The temperatures start to decrease on Milli Eğitim Bakanlığı Street and decrease further while passing TBMM deu to green areas and increase at the junctions of Kavaklidere Street. Occurrence of temperature difference between the junctions and the street is affected by the use underpass on the junction passing. The effect of wind is removed, which caused measuring higher values in the night measurements during the hot period. A similar case is observed in the Akay Underpass between the Kavaklidere and Cinnah Street. The temperatures start to decrease and vary towards the Cinnah Street. The temperatures suddenly rise at the Atakule Junction and increase depending on the busy traffic and pollutants, which was observed both in the day and night measurements. The temperatures decrease around Cumhurbaşkanlığ Street and a temperature sink occur. The temperatures rise again towards Turan Güneş Street and decrease to the south direction on the street depending on the elevation, and the temperatures remained high during the day measurements.

The southern cliff of the urban was not apparent as it was in the north both in the day and night measurements. The temperatures start to drop after Cinnah Street, and this drop continues to the middle of Turan Güneş Avenue. The temperature decrease in this area is usually associated with the elevation. After the Turan Güneş Avenue, the temperatures rise both during the day and at night. This area has very high SVFs but has plateau characteristic (morphologically). The temperature is further increased towards the rural area and the day temperatures continue to drop in April and June. 

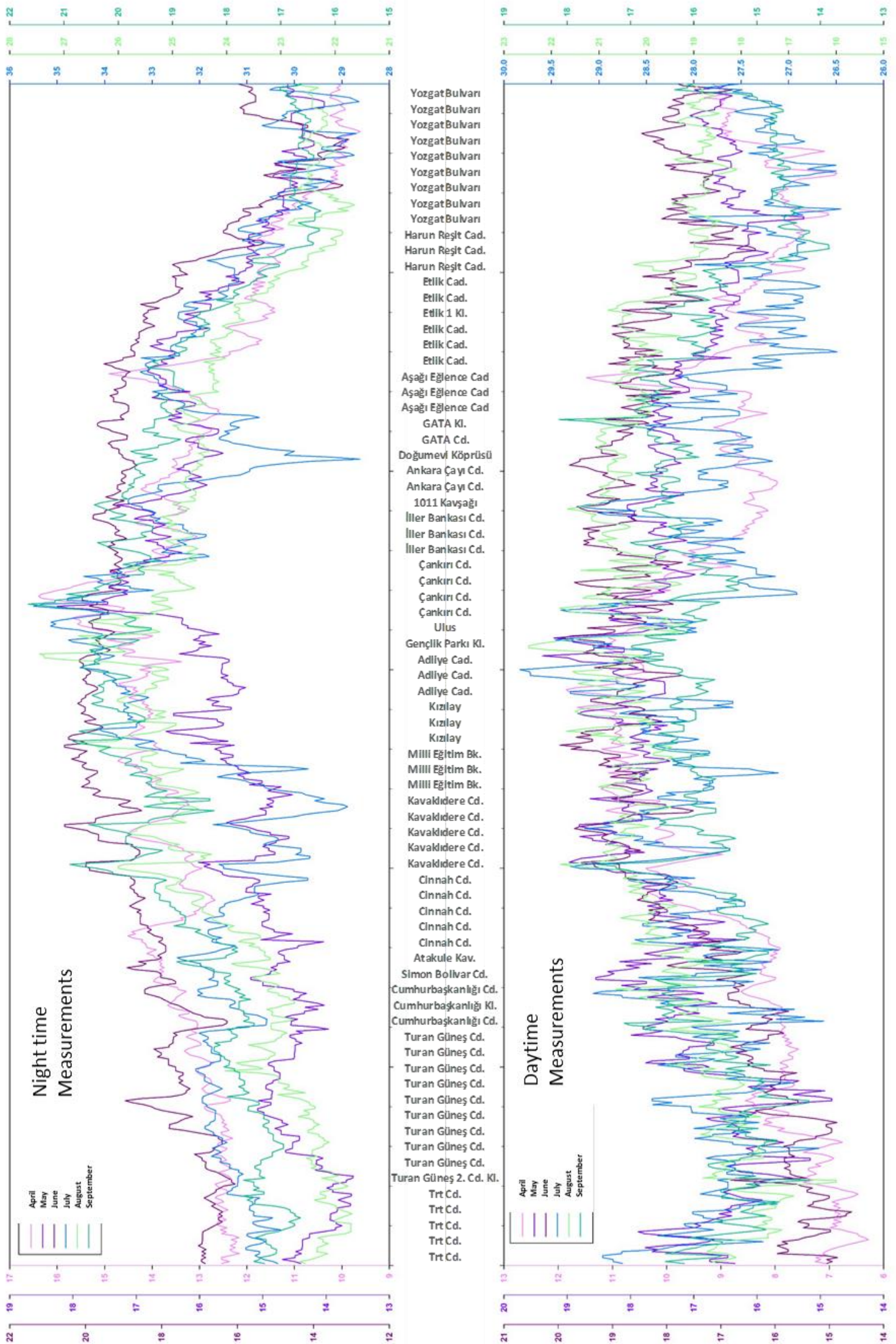

Figure 3. Hot period measurument results 


\section{Conclusion}

The following results were reached after the assessment of temperature measurements (daynight, hot-cold season) made in different sites in Ankara.

a) The peak of UHI is not only one location but has a varying characteristic in Ankara and occurs between Ulus and Kizilay Streets. The peak formed in Ulus and Kizılay is interrupted by urban spaces and green areas on Adliye Street and its surrounding. The peak may occur in Kizllay in the cold period but is formed in Ulus during the hot period. Although the cliff of UHI in Ankara may be replaced in time, it was formed at the Yükseltepe Junction and surrounding in the north and on Turan Güneş Avenue in the south during the measurements. The northern plateau of UHI extends between Çankırı Street and Ayvalı Bazaar, and the southern plateau extends between MEB Street and Turan Güneş Avenue. Along the plateau, the junctions and urban areas with high density display a temperature peak based on the surrounding. The green areas on the plateau are chilly depending on the surrounding and generate cool temperature sinks. The shape elements of UHI were more apparent in the night measurements and during the hot period. In the cold period, the shape elements of UHI disappear during the AB times and in the rainy weather conditions.

b) In the urban areas, the association between the temperatures and the elevation varies by the night, day and between the months. In the night measurements of cold period, the elevation-temperature relationship is inversed with the effect of inversion and the temperature increases as it is increased. The temperature decrease depending on the elevation in the hot night measurements and all day measurements, and the temperature varies by the elevation, weather and meteorological characteristics.

c) In Ankara, the SVF and the temperatures vary depending on the measurement time and season. At night, SVF are negatively correlated with the temperature in the hot period, and it is positively correlated in the cold period. During the day, there is a negative correlation between SVF and temperature in the cold period and a positive correlation in the hot period. This is associated with the period from the sunrise to the measurement time. When the heating time is increased during the day, the correlation between the SVF and the temperature is positive. At night, when the cooling time (radiation) is extended, there is a positive correlation; this is contrary to the theoretical information. This contradiction occurs because the measurement line has a heterogeneous land use.

d) The temperatures decrease both at night and in during daytime as one moves further away from city center. This decrease is approximately $0.4{ }^{\circ} \mathrm{C}$ per $1 \mathrm{~km}$ at night and around $0.2{ }^{\circ} \mathrm{C}$ during the day.

e) The UHII (amplitude of temperature) in night measurements was higher than the value measured during the day. Similarly, the UHI intensity measured in the hot period was higher than that of the cold period.

f) The measurements show that urban land use has an impact on the temperatures. As there are urban spaces and green areas between GATA Street and Adliye Street and around TBMM, the temperatures are lower. The temperatures also decrease around Kuğulu Park due to the green areas and 
the pool for swans in the Kuğulu Park. The temperatures are higher at the junctions due to high and busy traffic. The temperatures were higher on the streets having a characteristic of connected (adjoining) urban and such locations are urban canyons (Çankırı and Kızılay Streets). When there are roads intersecting the canyons, the temperatures may decrease and the effect of canyon is interrupted.

\section{Referanslar/References}

Ahmadi Venhari, A., Tenpierik, M., Taleghani, M. (2019). The Role of Sky View Factor and Urban Street Greenery in Human Thermal Comfort and Heat Stress in a Desert Climate. Journal of Arid Environments, 166, 68-76. https://doi.org/10.1016/J.JARIDENV.2019.04.009

Akalan, İ. (1984). Hava Kirlenmesi, Ankara Örneği. Ankara: TÜBİTAK.

Akman, Y. (1990). İklim ve Biyoiklim (Biyoiklim metotları ve Türkiye iklimleri). Ankara: Palme Yayın Dağıtım .

Alpar, R. (2003). Uygulamalı Çok Değişkenli İstatistiksel Yöntemlere Giriş 1. Ankara: Nobel Yayın Dağıtım.

Barış, M. E. (1995). Ankara Kentinde Hava Kirliliği Sorununun Çözümünde Peyzaj Mimarlı̆̆ Açısından Alınması Gereken Önlemler. Ankara Üniversitesi, Fen Bilimleri Enstitüsü, Yayımlanmamış Doktora Tezi, Ankara.

Betts, R. A., Falloon, P. D., Goldewijk, K. K., Ramankutty, N. (2007). Biogeophysical Effects of Land Use on Climate: Model Simulations of Radiative Forcing and Large-Scale Temperature Change. Agricultural and Forest Meteorology, 142(24), 216-233. https://doi.org/10.1016/j.agrformet.2006.08.021

Böhner, J., \& Antonić, O. (2009). Land-surface Parameters Specific to Topo-climatology. Developments in Soil Science, 33(C), 195-226. https://doi.org/10.1016/S0166-2481(08)00008-1

Bokwa, A., Hajto, M. J., Walawender, J. P., Szymanowski, M. (2015). Influence of Diversified Relief on the Urban Heat Island in the City of Kraków, Poland. Theoretical and Applied Climatology, 122(1-2), 365-382. https://doi.org/10.1007/s00704-015-1577-9

Bounoua, L., Safia, A., Masek, J., Peters-Lidard, C., Imhoff, M. L. (2009). Impact of Urban Growth on Surface Climate: A Case Study in Oran, Algeria. Journal of Applied Meteorology and Climatology, 48(2), $217-231$. https://doi.org/10.1175/2008JAMC2044.1

Carraro, E., Bonetta, S., Palumbo, F., Gilli, G. (2004). Urban and Rural Dewfall, Surface Moisture and Associated Canopylevel Air Temperature and Humidity Measurements for Vancouver, Canada. Annali Dell'Istituto Superiore Di Sanita, $40(1), 117-140$.

Chen, Y., \& Wong, N. H. (2006). Thermal Benefits of City Parks. Energy and Buildings, 38(2), 105-120. https://doi.org/10.1016/j.enbuild.2005.04.003

Cheng, M. T., Tsai, Y. I. (2000). Characterization of Visibility and Atmospheric Aerosols in Urban, Suburban, and Remote Areas. Science of the Total Environment, 263(1-3), 101-114. https://doi.org/10.1016/S0048-9697(00)00670-7

Chieppa, J., Bush, A., Mitra, C. (2018). Using “"Local Climate Zones”" to Detect Urban Heat Island on Two Small Cities in Alabama. Earth Interactions, 22(16). https://doi.org/10.1175/EI-D-17-0020.1

Chow, W. T. L., Pope, R. L., Martin, C. A., Brazel, A. J. (2011). Observing and Modeling The Nocturnal Park Cool Island of an Arid City: Horizontal and Vertical Impacts. Theoretical and Applied Climatology, 103(1), 197-211. https://doi.org/10.1007/s00704-010-0293-8

Çalışkan, O., Türkoğlu, N. (2014). Ankara'da Termal Konfor Koşulların Eğilimi ve Şehirleşmenin Termal Konfor Koşulları Üzerine Etkisi. Coğrafi Bilimler Dergisi, 12(2), 119-132.

Çiçek, İ. (2004). Ankara'da Şehirleşmenin Yağış Üzerine Etkisi. Fırat Üniversitesi, Sosyal Bilimler Dergisi, 14(1), 1-17.

Çiçek, İ. (2005). Ankara'da Şehir ve Kırsal Sıcaklık Farklarındaki Değişiklikler (1970-2002). Fırat Üniversitesi Sosyal Bilimler Dergisi, 15(2), 1-16.

Çiçek, İ., \& Doğan, U. (2005). Ankara'da Şehir Isı Adasının İncelenmesi. Coğrafi Bilimler Dergisi, 3(1), 57-72.

Çiçek, İ., Yılmaz, E., Türkoğlu, N., Çalışkan, O. (2013). Ankara Şehrinde Yüzey Sıcaklıklarının Arazi Örtüsüne Göre Mevsimsel Değişimi. Uluslararası İnsan Bilimleri Dergisi, 10(1), 621-640.

Debbage, N. (2013). Sky-view Factor Estimation: A Case Study of Athens, Georgia. Geographical Bulletin - Gamma Theta 
Upsilon, 54(1), 49-57.

Doick, K. J., Peace, A., Hutchings, T. R. (2014). The Role of One Large Greenspace in Mitigating London's Nocturnal Urban Heat Island. Science of the Total Environment, 493, 662-671. https://doi.org/10.1016/j.scitotenv.2014.06.048

Eastin, M. D., Baber, M., Boucher, A., Di Bari, S., Hubler, R., Stimac-Spalding, B., Winesett, T. (2018). Temporal Variability of the Charlotte (sub) Urban Heat Island. Journal of Applied Meteorology and Climatology, 57(1), 81-102. https://doi.org/10.1175/JAMC-D-17-0099.1

Elagib, N. A. (2011). Evolution of Urban Heat Island in Khartoum. International Journal of Climatology, 31(9), 1377-1388. https://doi.org/10.1002/joc.2159

Erol, O. (1985). Genel Klimatoloji. Ankara: Gazi Büro Kitabevi.

Findell, K. L., Pitman, A. J., England, M. H., Pegion, P. J., Findell, K. L., Pitman, A. J., ... Pegion, P. J. (2009). Regional and Global Impacts of Land Cover Change and Sea Surface Temperature Anomalies. Journal of Climate, 22(12), 32483269. https://doi.org/10.1175/2008JCLI2580.1

Gaillard, M. J., Sugita, S., Mazier, F., Trondman, A. K., Broström, A., Hickler, T., ... Seppä, H. (2010). Holocene Land-cover Reconstructions for Studies on Land Cover-climate Feedbacks. Climate of the Past, 6(4), 483-499. https://doi.org/10.5194/cp-6-483-2010

Häntzschel, J., Goldberg, V., Bernhofer, C. (2005). GIS-Based Regionalisation Of Radiation,Temperature And Coupling Measures In Complex Terrain For Low Mountain Ranges. Meteorological Applications, 12(1), $33-42$. https://doi.org/10.1017/S1350482705001489

Hart, M. A., Sailor, D. J. (2009). Quantifying the Influence of Land-use and Surface Characteristics on Spatial Variability in the Urban Heat Island. Theoretical and Applied Climatology, 95(3-4), 397-406. https://doi.org/10.1007/s00704-0080017-5

Ibrahim, A. A., Nduka, I. C., Iguisi, E. O., Ati, O. F. (2011). An Assessement of the Impact of Sky View Factor (SVF) on the Micro-climate of Urban Kano. Australian Journal of Basic and Applied Sciences, 5(7), 81-85.

Jahangir, M. S., Moghim, S. (2019). Assessment of the Urban Heat Island In The City of Tehran Using Reliability Methods. Atmospheric Research, 225, 144-156. https://doi.org/10.1016/J.ATMOSRES.2019.03.038

Kalnay, E., Cai, M. (2003). Impact of Urbanization and Land-use Change on Climate. Nature, 423(6939), 528-531. https://doi.org/10.1038/nature01675

Karaca, M., Tayanc, M., Toros, H. (1995). Effects of Urbanization on Climate of Istanbul and Ankara. Atmospheric Environment, 29(23), 3411-3421. https://doi.org/10.1016/1352-2310(95)00085-D

Kastendeuch, P. P. (2013). A Method to Estimate Sky View Factors from Digital Elevation Models. International Journal of Climatology, 33(6), 1574-1578. https://doi.org/10.1002/joc.3523

Koçman, A. (1993). Türkiye İklimi. İzmir: Ege Üniversitesi Edebiyat Fakültesi Yayınları No:72.

Landsberg, H. E. (1981). The Urban Climate. London: Academic Press.

Lee, S. H., Song, C. K., Baik, J. J., Park, S. U. (2009). Estimation of Anthropogenic Heat Emission in The Gyeong-In Region of Korea. Theoretical and Applied Climatology, 96(3-4), 291-303. https://doi.org/10.1007/s00704-008-0040-6

Lin, C. Y., Chen, F., Huang, J. C., Chen, W. C., Liou, Y. A., Chen, W. N., Liu, S. C. (2008). Urban Heat Island Effect and Its Impact on Boundary Layer Development and Land-sea Circulation Over Northern Taiwan. Atmospheric Environment, 42(22), 5635-5649. https://doi.org/10.1016/j.atmosenv.2008.03.015

Mathew, A., Khandelwal, S., Kaul, N. (2016). Spatial and Temporal Variations of Urban Heat Island Effect and The Effect of Percentage Impervious Surface Area and Elevation on Land Surface Temperature: Study of Chandigarh city, India. Sustainable Cities and Society, 26, 264-277. https://doi.org/10.1016/j.scs.2016.06.018

Melhuish, E., Pedder, M. (1998). Observing an Urban Heat Island by Bicycle. Weather, 53(4), $121-128$. https://doi.org/10.1002/j.1477-8696.1998.tb03974.x

Memon, A. R., Leung, D. Y., Chunho, L. (2008). A Review on The Generation, Determination and Mitigation of Urban Heat Island. Journal of Environmental Sciences, 20, 120-128.

Nichol, J. E., Fung, W. Y., Lam, K., Wong, M. S. (2009). Urban Heat Island Diagnosis Using ASTER Satellite Images And "In Situ" Air Temperature. Atmospheric Research, 94(2), 276-284. https://doi.org/10.1016/j.atmosres.2009.06.011 
Oke, T. R. (1973). City Size and The Urban Heat Island. Atmospheric Environment (1967), 7(8), 769-779. https://doi.org/10.1016/0004-6981(73)90140-6

Oke, T. R. (1982). The Energetic Basis of The Urban Heat Island. Quarterly Journal of the Royal Meteorological Society, 108(455), 1-24. https://doi.org/10.1002/qj.49710845502

Oke, T. R. (2002). Boundary Layer Climates (Secon Edit). Vancouver: Routledge.

Peng, S., Piao, S., Ciais, P., Friedlingstein, P., Ottle, C., Bréon, F. M., ... Myneni, R. B. (2012). Surface Urban Heat Island Across 419 Global Big Cities. Environmental Science and Technology, 46(2), 696-703. https://doi.org/10.1021/es2030438

Pielke, R. A., Pitman, A., Niyogi, D., Mahmood, R., McAlpine, C., Hossain, F., ... de Noblet, N. (2011). Land Use/land Cover Changes and Climate: Modeling Analysis and Observational Evidence. Wiley Interdisciplinary Reviews: Climate Change, 2(6), 828-850. https://doi.org/10.1002/wcc.144

Qaid, A., Lamit, H. Bin, Ossen, D. R., Rasidi, M. H. (2018). Effect of The Position of The Visible Sky in Determining The Sky View Factor on Micrometeorological and Human Thermal Comfort Conditions in Urban Street Canyons. Theoretical and Applied Climatology, 131(3-4), 1083-1100. https://doi.org/10.1007/s00704-016-2023-3

Qiao, Z., Tian, G., Zhang, L., Xu, X. (2014). Influences of Urban Expansion on Urban Heat Island in Beijing During 19892010. Advances in Meteorology, 2014, 1-11. https://doi.org/10.1155/2014/187169

Sanır, F. (1948). Ankara ve Çevresinin İklimi Hakkında. Ankara Üniversitesi Dil ve Tarih-Coğrafya Fakültesi Dergisi, 4, 291318.

Schatz, J., Kucharik, C. J., Schatz, J., Kucharik, C. J. (2014). Seasonality of the Urban Heat Island Effect in Madison, Wisconsin. Journal of Applied Meteorology and Climatology, 53(10), 2371-2386. https://doi.org/10.1175/JAMC-D-140107.1

Singh, P., Kikon, N., Verma, P. (2017). Impact of Land Use Change and Urbanization on Urban Heat Island in Lucknow City, Central India. A Remote Sensing Based Estimate. Sustainable Cities and Society, 32, $100-114$. https://doi.org/10.1016/j.scs.2017.02.018

Stocker, T. F., Qin, D., Plattner, G.-K., Tignor, M., Allen, S. K., Boschung, J., ... Midgley, P. M. (2014). Climate Change 2013 - The Physical Science Basis. Climate Change 2013 - The Physical Science Basis. Cambridge, United Kingdom and New York, NY, USA: Cambridge University Press. https://doi.org/10.1017/cbo9781107415324

Streutker, D. R. (2002). A Remote Sensing Study of the Urban Heat Island of Houston, Texas. International Journal of Remote Sensing, 23(13), 2595-2608. https://doi.org/10.1080/01431160110115023

Tomlinson, C. J., Chapman, L., Thornes, J. E., Baker, C. J. (2011). Including The Urban Heat Island in Spatial Heat Health Risk Assessment Strategies: A Case Study for Birmingham, UK. International Journal of Health Geographics, 10(1), 14p. https://doi.org/10.1186/1476-072X-10-42

Türkiye İstatistik Kurumu (TÜIK, 2019). İllere Göre Adrese Dayalı Nüfus Miktarları 08.07.2019 tarihinde www.tuik.gov.tr adresinden edinilmiştir.

Türkoğlu, N., Çalışkan, O., Çiçek, İ., Yılmaz, E. (2012). Şehirleşmenin Biyoklimatik Koşullara Etkisinin Ankara Ölçeğinde İncelenmesi. Uluslararası Insan Bilimleri Dergisi, 9(1), 932-955.

Voogt, J. A., Oke, T. R. (1998). Radiometric Temperatures of Urban Canyon Walls Obtained From Vehicle Traverses. Theoretical and Applied Climatology, 60(1-4), 199-217. https://doi.org/10.1007/s007040050044

World City Populations (WCP, 2019). Dünyadaki en kalabalık şehir nüfusları 08.07.2019 tarihinde http://worldpopulationreview.com/world-cities/ adresinden edinilmiştir.

Yamashita, S. (1996). Detailed Structure of Heat Island Phenomena From Moving Observations From Electric Tram-cars in Metropolitan Tokyo. Atmospheric Environment, 30(3), 429-435. https://doi.org/10.1016/1352-2310(95)00010-0

Yang, G., Bowling, L. C., Cherkauer, K. A., Pijanowski, B. C., Niyogi, D. (2010). Hydroclimatic Response of Watersheds to Urban Intensity: An Observational and Modeling-Based Analysis for the White River Basin, Indiana. Journal of Hydrometeorology, 11(1), 122-138. https://doi.org/10.1175/2009JHM1143.1

Yılmaz, E. (2016). Uydu Görüntüleri ile Adana Yüzey Isı Adası. Coğrafi Bilimler Dergisi. 13 (2), 115-138.

Yüksel, Ü. D., Yılmaz, O. (2008). Ankara Kentinde Kentsel Isı Adası Etkisinin Yaz Aylarında Uzaktan Algılama ve Meteorolojik Gözlemlere Dayalı Olarak Saptanması ve Değerlendirilmesi. Gazi Üniv. Müh. Mim. Fak. Der, 23(4), 937952.

Yüksel, Ü., Kuntay, O. (2009). Effects of Urbanization on the Climate of Ankara. Içinde 5th Urban Research Symposium: 
Cities and Climate Change: Responding to an Urgent Agenda Marseille, . Marseille, France.

Zhang, D. L., Shou, Y. X., Dickerson, R. R., Chen, F. (2011). Impact of Upstream Urbanization on The Urban Heat Island Effects Along The Washington-Baltimore Corridor. Journal of Applied Meteorology and Climatology, 50(10), 20122029. https://doi.org/10.1175/JAMC-D-10-05008.1

Zheng, Z., Ren, G., Wang, H., Dou, J., Gao, Z., Duan, C., ... Yang, Y. (2018). Relationship Between Fine-Particle Pollution and the Urban Heat Island in Beijing, China: Observational Evidence. Boundary-Layer Meteorology, 169(1), 93-113. https://doi.org/10.1007/s10546-018-0362-6

Zhou, D., Zhao, S., Liu, S., Zhang, L., Zhu, C. (2014). Surface Urban Heat Island in China's 32 Major Cities: Spatial Patterns and Drivers. Remote Sensing of Environment, 152, 51-61. https://doi.org/10.1016/j.rse.2014.05.017

Zhou, H. M., Ge, W. Q., Yang, H. Q., Liu, J., Yang, Y. L. (2015). Improving The Effect of Greening on Heat Island in Urban Residential Districts Based on Remote Sensing and GIS analysis. Journal of Tropical Meteorology, 21(3), 303-310. https://doi.org/10.16555/j.1006-8775.2015.03.010 